\title{
O ACENTO: DUAS ALTERNATIVAS DE ANÁLISE
}

Leda Bisol

\section{INTRODUÇÃO ${ }^{1}$}

A análise do acento aqui apresentada fundamenta-se em Halle \& Vergnaud (1987), cuja proposta, alicerçada em Liberman \& Prince (1977), Hayes(1981), Prince (1983) e Hammond (1986), constitui a linha mais avançada da Fonologia Métrica.

Comecemos por considerar alguns pontos da fonologia gerativa tradicional, elaborada por Chomsky and Halle em Sound Pattern of English, SPE (1968), representada neste livro por Mira Mateus, que interpreta o sistema acentual do português como um conjunto sucinto de regras com vistas a congregar simplicidade e generalização.

A teoria clássica (SPE) tem por ponto de partida a ideia de que o acento é uma propriedade de segmentos individuais, vogais propriamente que se expressa por meio de traços binários do tipo: vogais em que o traço [+ac] está presente versus vogais em que esse traço está ausente [-ac]. E, a fim de que a distinção, apropriada para indicar o acento principal, também possa expressar os diferentes graus de acentos subsidiários, SPE admite que [-ac] tem múltiplos valores: [ac1], [ac2], [ac3] etc., dependendo do nível da inserção morfológica no processo cíclico. Concomitantemente vale-se de recursos auxiliares como a regra rítmica que enfraquece todos os acentos de um grau na passagem do ciclo.

A primeira reação a essa análise, dentro dos mesmos princípios gerais da teoria gerativa, deve-se a Liberman (1975) e a Liberman and Prince (1977) e tem por motivação básica o fato de o modelo clássico (SPE) permitir teoricamente $\mathrm{n}$-ários acentos, quando, na verdade, as línguas do mundo os têm limitados. A grande diferença é que o acento deixa de ser entendido como uma propriedade de segmentos individuais para ser interpretado como o resultado ela estruturação hierárquica dos constituintes prosódicos, cujas unidades básicas são a sílaba, o pé e a palavra. Esses constituintes

1 Os meus agradecimentos a Leo Wetzels e a Celso Luft pela leitura da versão original com comentários e valiosas sugestões. Agradeço também aos alunos-bolsistas de Iniciação Científica ligados ao projeto VARSUL da UFRGS, a execução do levantamento estatístico que permitiu elaborar os quadros apresentados na seção 2: Clarissa Gregory Brunet. Gislaine Pacheco, Jorge Ricardo Abrahão, Lúcia Lovato Leiria e Silvio Henrique Cabreira. 
desenvolvem, da mesma forma que os da sintaxe, entre as unidades que os compõem, uma relação de dominante e dominado. O elemento dominante comumente é referido como cabeça de constituinte.

O que é sobretudo interessante na proposta de Liberman and Prince é a representação do acento como uma questão de relativa proeminência de sílabas que se expressa por meio de árvores de estruturas binárias nas quais cada par de nós irmãos é rotulado forte/fraco ou vice-versa (sw ou ws), dependendo da posição do mais forte. O sentido da rotulação é puramente relativo de modo que sílabas isoladas não são interpretáveis. Desta forma, sílabas sempre dominadas por $\mathrm{s}$ recebem o acento primário, enquanto recebem o acento secundário aquelas em que houve alguma incidência de $\mathrm{w}$, recaindo a atonicidade maior sobre as que somente $\mathrm{w}$ receberam.

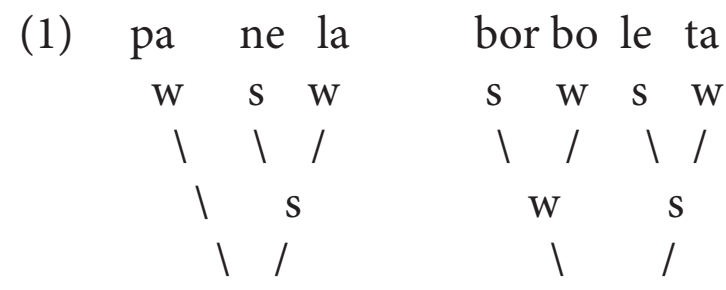

Os autores ainda preservam o traço [-acento] do modelo clássico, em virtude de certas proeminências não serem alcançadas com uso exclusivo da estrutura arbórea, como ocorre no inglês. O exemplo extraído de Hayes (1981) o mostra comparativamente:

(2)

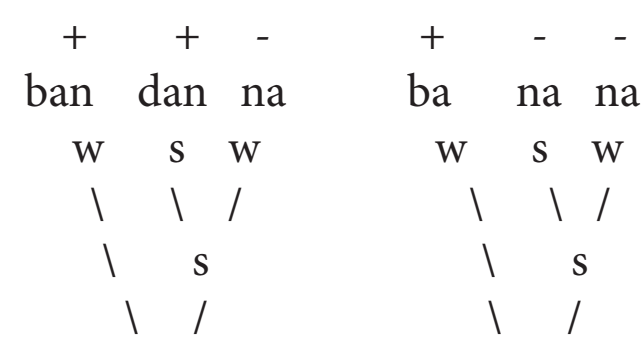

Com os trabalhos de Prince (1976), Selkirk(1980), a estrutura métrica se enriquece, o pé ganha um status independente e o traço [-acento] se torna dispensável. O ponto central é a sílaba, ou melhor, o grau de subordinação entre as sílabas de um pé, embora a proeminência entre os pés também tenha um papel na determinação do acento principal, porquanto esse incide sobre a sílaba mais forte do pé mais forte.

A teoria métrica oferece, segundo Hayes (1981, p 8-10), comparativamente uma representação melhor do acento pelas seguintes 
razões: em primeiro lugar, o acento não se realiza localmente e exige no mínimo duas sílabas para estabelecer um contorno de proeminência: em segundo lugar, resolve o dilema do ordenamento disjuntivo, eliminando-o de todo da teoria fonológica, i.e., não há mais necessidade de um conjunto de regras ordenadas disjuntivamente, especialmente postas para a descrição do acento na teoria clássica. O que se necessita agora é apenas a regra que organiza as sílabas em unidades prosódicas com um elemento dominante, que por pé métrico se denomina. É nessas linhas que se insere esta análise.

Embora as primeiras abordagens da Fonologia Métrica se valessem do diagrama-árvore para visualizar os pés métricos das palavras, através da rotulação forte/ fraco ( $\mathrm{s} / \mathrm{w}$ ) ou vice-versa de suas sílabas, com um refinamento teórico assentado na atribuição de acento de muitas línguas, parametrizado por Hayes (1981), o modelo de Halle \& Vergnaud vale-se de uma grade métrica parentetizada que incorpora elementos de ambas as teorias precedentes, a da árvore e a só-grade com parâmetros específicos para os diferentes níveis da organização métrica.

Enquanto a teoria da árvore representa por um diagrama arbóreo a organização hierárquica do material fonológico, a teoria só-grade, desenvolvida por Prince (1983), opera com princípios distintos da fonologia segmental, diagramando um material de estrutura autônoma, representado minimamente em três níveis. Como primeira aproximação desses modelos, observemos (3) onde se vê à esquerda a notação arbórea (linhas verticais indicam cabeça de constituintes) e à direita a correspondente notação de grade.

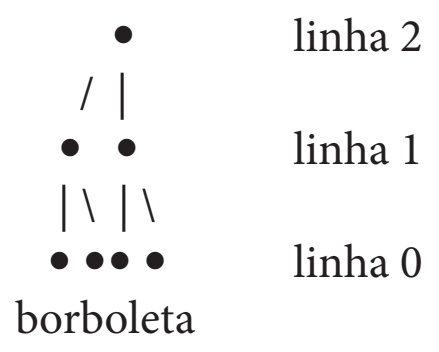

O diagrama em (3) representa a idéia norteadora da hipótese de Liberman \& Prince de que o acento está relacionado à maneira com que os elementos são agrupados em árvores métricas de ramificações binárias, desenvolvendo como constituintes uma relação de dependência entre os nós de rótulo forte $(\mathrm{s})$ e os de rótulo fraco $(\mathrm{w})$ de tal modo que unicamente sobre (s) venha a incidir o acento primário.

No que diz respeito à grade métrica que (3) insinua e (4) prioriza, os mecanismos de análise atendem a três requisitos: a enumeração das sílabas 
ou moras na linha 0 ; a regra que confere asterisco na linha 1 à segunda mora de uma sílaba pesada, conhecida como Sensibilidade Quantitativa(SQ), 'Quantity-Sensitivity', em línguas sensíveis ao peso silábico.

No modelo arbóreo, aprimorado por Hayes, sílabas pesadas são imanentemente inábeis de situarem-se na posição fraca de um pé, o que impede, anunciado de forma negativa, que a posição fraca de um pé venha a dominar uma sílaba pesada. No modelo da grade métrica, duas marcas emergem sobre essas sílabas, uma das quais é levada para o nível imediatamente superior, como o elemento dominante, de acordo com o princípio da escala da hierarquia sonora. Nem todas as línguas, porém, são sensíveis à sílaba quantitativamente, razão pela qual o parâmetro da sensibilidade quantitativa coloca como opção a escolha de informações sobre a estrutura interna da rima.

Retomando a grade métrica, que se desenvolve minimamente em três níveis, o da mora ou sílaba, o do pé e o da palavra como (4) representa, ainda na linha 1 a Regra da Grade Perfeita (GP) distribui asteriscos em sílabas de distâncias alternantes, da esquerda para a direita ou da direita para a esquerda, levando em conta marcas já existentes. Sua função é claramente criar seqüências de unidades acentuadas/não-acentuadas. E a Regra Final (RF) leva para o topo da grade, à extrema direita ou à extrema esquerda, em conformidade com instruções de língua particular, o asterisco indicativo do acento principal:

$\begin{array}{lrrrll}* & * & * & * & (\mathrm{RF}) & \text { linha } 2 \\ { }^{*} & * & * & * & (\mathrm{GP})(\mathrm{SQ}) & \text { linha } 1 \\ \mathrm{CVC} & \mathrm{CV} & \mathrm{CV} & \mathrm{CV} & & \text { linha } 0 \\ \text { bor } & \text { bo le } & \text { ta } & & \end{array}$

No modelo de Ha1le \& Vergnaud, o plano do acento também consiste em uma grade-métrica, enriquecida pela informação sobre a estrutura de constituintes, não necessariamente binários, cujos limites são indicados por parênteses e cujas cabeças são projetadas na linha 1. Tomemos (5) provisoriamente como ilustração:

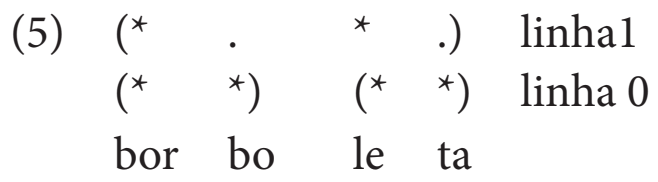


Organiza-se então o constituinte da linha 1 cuja cabeça se projeta. na linha 2. Consecutivamente, fundem-se ('conflation') os asteriscos das linhas 1 e 2, limpando a grade, mas deixando intato o último:

(6) $\begin{array}{lllll}( & & * & ) & \text { Linha2 } \\ \left({ }^{*}\right. & . & * & .) & \text { linha1 } \\ \left({ }^{*}\right. & \star & \left({ }^{*}\right. & \star & \text { linha } 0 \\ \text { bor } & \text { bo } & \text { le } & \text { ta } & \end{array}$

Consideremos, passo a passo, esse recurso formal. $\mathrm{O}$ primeiro parâmetro diz respeito à formação de constituintes.

No plano autossegmental em que se desenrola a abordagem de Halle \& Vergnaud, organizam-se os mentos acentuáveis em constituintes métricos, com um elemento marcado, a cabeça, sem ligação direta com a substância fonológica ou fonética dessas e de outras unidades que entram na constituição da palavra. Na linha 0 , as moras ou sílabas perfilam-se em constituintes, cujas cabeças são projetadas na linha 1, onde cada cabeça representa por si mesmo o constituinte tal qual o formalismo da teoria $\mathrm{X}$ barra. O número de constituintes possíveis, assim como sua variação, é limitado. Daí o parâmetro que diz respeito a limites:

(7) Os constituintes são limitados ou ilimitados.

Isso significa que as línguas fazem opções entre constituintes limitados (binário, ternário) ou ilimitados, muitas vezes com variações de um nível lexical para outro.

Se os padrões de acento das línguas do mundo se expressam por meio de constituintes, é de esperar que a Teoria não só forneça parâmetros que digam respeito à extensão do constituinte mas também informe sobre posicionamento da cabeça e ponto de partida da organização métrica. Daí o parâmetro seguinte:

(8) Os constituintes possuem cabeça terminal ou não.

A Teoria prevê três posições de cabeça: terminal à esquerda $\left({ }^{*}.\right)$, terminal à direita. $\left(.{ }^{*}\right)$ e não-terminal $\left(.{ }^{*}\right.$.) Por fim, a organização dos elementos métricos em constituintes pode começar pela borda direita como pela borda esquerda da palavra. Também pode acontecer que em dada língua os constituintes envolvidos com o acento primário tenham 
uma direção e tenham outra com o secundário. Então o parâmetro da direcionalidade informa:

(9) Direção : direita à esquerda; esquerda à direita.

Estas regras estão sumariadas em (10), e constituem as diretrizes desta análise.

(10) Princípios de Formação da Grade Métrica

a. Construa constituintes na linha L.

Parâmetros: (i) cabeça terminal ou não.

(ii) cabeça localizada à direita,. no meio ou à esquerda.

(ii) constituinte limitado ou ilimitado.

(iii) iterativo ou não

(iv) governo (direita à esquerda ou vice-versa),

b.Localize as cabeças na linha L1.

Parâmetros: (v) constituintes limitados ou ilimitados

c.Localize as cabeças de L1 na linha L2 .

d.Fusão das últimas linhas, com preservação do asterisco de periferia.

Retomando o que foi dito, as instruções acima postas determinam se o constituinte tem cabeça terminal ou não (i); qual a posição desta cabeça (ii); se é limitado, binário, ternário ou sem limites (ii); se sua aplicação é exaustiva no sentido de envolver toda a palavra ou não (iii); e se os constituintes se estabelecem a partir da borda direita ou esquerda do vocábulo. As cabeças projetadas na linha 1 formam também constituintes, com cabeça(s) localizada(s) na tinha 2 (c).

A noção de cabeça é inerente à de constituinte, seja ele sintático ou prosódico. Nesse, em que equivale ao pé métrico, cujo domínio se expressa forte/fraco $(\mathrm{s} / \mathrm{w})$ ou fraco/forte $(\mathrm{w} / \mathrm{s})$, aparecem, por vezes, ao lado dos que se formam naturalmente com cabeça à direita ou à esquerda (e não terminal previsto também pela Teoria), constituintes defectivos ('default'), ou seja, pés monossilábicos que são cabeças de si mesmos. Assim, ao estabelecerem-se constituintes binários de cabeça à esquerda numa sequência ímpar a partir da borda direita, em (11), onde números indicam sílabas, a sílaba indicada por (1) forma um constituinte de um elemento só, que é necessariamente cabeça, conforme prevê a Teoria de Halle \& Vergnaud. 


$\begin{array}{cccccc}(11) & \left({ }^{*}\right) & \left({ }^{*}\right. & .) & \left({ }^{*}\right. & .) \\ 1 & 2 & 3 & 4 & 5 \\ & & & & \\ & & & \\ & {[+\mathrm{Ex}]} & & {[-\mathrm{Ex}]} \\ \text { rápida } & & \\ \text { número } & \text { rapidaménte } \\ \text { ludíbrio } & \text { ludibrióso }\end{array}$

Por fim, a extrametricidade pode ser atribuída de dois modos: por regra ou por marca lexical. Nesta, o item recebe marca lexical da extrametricidade, e tem um âmbito mais restrito, próprio de casos de exceção. Naquela, é mais geral.

\section{2-DADOS}

O acento em português, como no espanhol, na interpretação de Harris (1983), está sujeito à restrição da janela, no sentido de que, a contar da borda direita da palavra, nunca vai além da terceira sílaba.

Para as considerações que seguem, faz-se necessário ter em mente a estrutura vocabular. Com respeito às classes de palavras, há diferenças entre verbos e não-verbos na sua estrutura morforlógica. Não-verbos compreendem duas partes: radical $^{2}+$ desinência; esta com dois subcomponentes: vogal temática ou marca de gênero,ambas aqui referidas como vogal temática $(\mathrm{VT})$, e marca de número $(\mathrm{N})$. Verbos, que também compreendem duas partes, têm mais subcomponentes fora do radical: radical (R), vogal temática (VT), morfema de modo-tempo-aspecto (MTA) e morfema de número-pessoa (NP). Diferentemente dos não-verbos, todos os monemas dos verbos, exceto VT, são portmanteaux (morfemas cumulativos). Em ambas as classes, todavia, quaisquer morfemas fora do radical podem estar ausentes em dada forma.

Verbos se distinguem pela vogal temática: tema em -a, tema em-e, tema em -i. Não-verbos, segundo Mattoso Câmara Júnior(1970:87-96), subdividem-se em dois grupos: a) palavras com vogal temática (posição ocupada também pelo morfema de gênero) que apresentam as formas

2 Para nossos propósitos, Radical fica entendido como a base do processo derivacional que pode ou não coincidir com a raiz primitiva. É, pois, a forma base a que se acrescentam os sufixos ou desinências, entre os quais se coloca a vogal temática. 
subjacentes/a,e,o/, manifestando-se as duas últimas na maioria dos dialetos como $[i, u]$, ex.: casa, parede, bolo; b) palavras sem vogal temática com terminação em consoante ou vogal plena: café, pomar, papel. Do exposto infere-se que o item lexical compreende o radical e a desinência e que esta distingue verbos de não verbos, como se lê em (13):

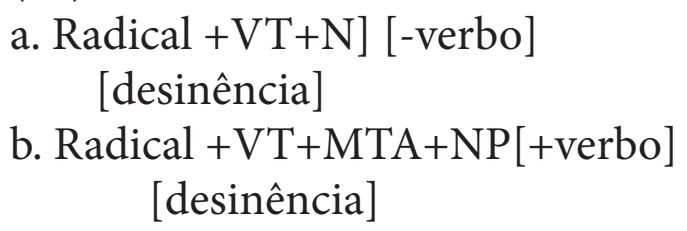

Passemos agora à apresentação dos fatos:

I -As palavras acabadas em vogal, com acento na segunda sílaba, a partir da borda direita, constituem o padrão geral. A vogal final temática (VT), na subjacência /a,e,o/, ou marca de gênero, está sujeita às regras de elevação, do sistema e, o mais das vezes, apagada, no processo derivacional, se for seguida de outra vogal.

Porque as palavras sem vogal temática fazem diminutivo em -zinho, independentemente de sua terminação em vogal ou consoante, e as palavras com vogal temática o fazem com exceções, em - inho, vamos nos valer deste teste na classificação dos dados, com vistas a oferecer apoio a posições tomadas nesta análise, sobretudo no que diz repeito a unificar a estrutura silábica final subjacente de palavras sem vogal temática, acabadas ou não em consoante, como o faz a segunda proposta aqui apresentada. A classe mencionada em I opta por -inho. Raras palavras admitem - zinho.

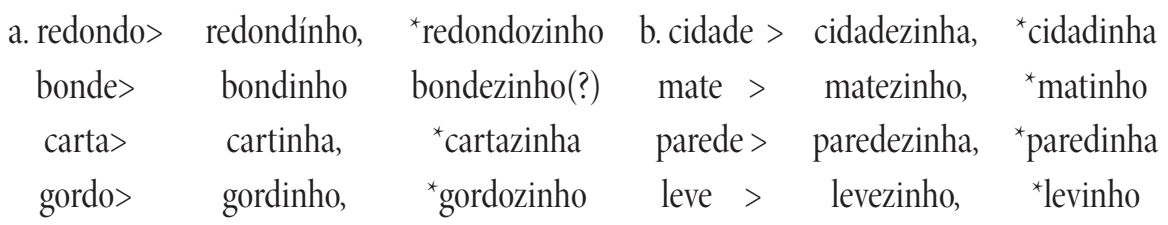

II - Contrapõem-se a (I) palavras com acento na terceira sílaba (sempre a contar da borda direita), uma classe relativamente menor embora frequentes na linguagem técnica e científica, também terminadas em vogal temática ou de gênero com a característica acima mencionada. Todavia, entre os sufixos referidos optam por -zinho. Raras aceitam -inho. E têm a peculiaridade, apontada por Harris (1983) com referência ao espanhol, de nunca apresentarem sílaba de rima ramificada na segunda posição. 


$$
\begin{array}{llll}
\text { a.número }>\text { numerozinho. } & { }^{*} \text { numerinho } & \text { b. }{ }^{*} \text { cádastro, } & \text { mas cadástro } \\
\text { lâmpada> lampadazinha, }{ }^{*} \text { lampadinha } & { }^{*} \text { cóvarde, } & \text { mas covárde } \\
\text { câmara> camarazinha, }{ }^{*} \text { camarinha } & { }^{*} \text { párente, } & \text { mas parénte } \\
\text { cérebro> cerebrozinho. } & { }^{*} \text { cerebrinho } & { }^{*} \text { sárgento, } & \text { mas sargénto }
\end{array}
$$

Quando palavras desta classe se apresentam com -inho, já passaram por um processo de elisão que as converteu em paroxítonas, do tipo exemplificado em (14).

As exceções referentes à não-existência de sílaba intermediária com ditongo ou consoante final (Rosáura mas não ${ }^{*}$ Rósaura; sargénto mas não *sárgento) não ferem a generalidade; uma delas é apenas aparente e compreende duas palavras eruditas séquano e séqüito, que mostram na segunda síl aba a sequência $/ \mathrm{kw} /$, o único ditongo crescente não diretamente relacionado a hiato, que tem merecido diferentes interpretações, inclusive a de constituir uma unidade monofonemática representada lexicalmente. De toda forma, o glide de um ditongo crescente não teria a propriedade de tornar pesada a sílaba. A outra é de empréstimo pénalti que, todavia, apresenta a variante com acento na segunda sílaba: pénalti - pênalti.

Nesta classe se incluem as proparoxítonas do paradigma verbal onde a consoante final faz parte dos morfemas número/pessoa: mos e is. O último, em virtude de favorecer a formação de ditongo junto à vogal precedente, cria na superfície uma palavra paroxítona.

$$
\begin{array}{ll}
\text { cantávamos vendíamos } & \text { partíssemos } \\
\text { cantáveis vendíeis } & \text { partíeis (em desuso) }
\end{array}
$$

III - As palavras acabadas em consoante /R,L,S/ (as nasais serão consideradas mais adiante), constituídas somente de radical, i.é, sem VT, levam acento na sílaba final na maioria dos casos. A marca de gênero, naquelas que a admitem por acréscimo, como a de número, não altera a posição do acento. No processo derivacional mencionado optam pela variante -zinho.

$\begin{array}{llll}\text { mulhér } & \text { mulherzinha } & { }^{*} \text { mulherinha } & \text { mulheres } \\ \text { pomar } & \text { pomarzínho } & { }^{*} \text { pomarinho } & \text { pomares } \\ \text { jornál } & \text { jornalzinho } & { }^{*} \text { jornalinho } & \text { jornais } \\ \text { marquês } & \text { marquesinho } & ------- & \text { marqueses, marquesa } \\ \text { francês } & \text { francesinho } & ------- & \text { franceses, francesa } \\ \text { irmão } & \text { irmãozinho } & ------ & \text { irmãos, irmã }\end{array}$

3 Note-se que a variante com inho toma, por vezes, sentido específico como, por exemplo, tem significado depreciativo em mulherinha (mulher à -toa). 
As duas últimas, acabadas em /S/, deixam aberta a possibilidade de dupla interpretação. Pode-se supor que a terminação rejeite a variante -zinho por razões específicas, ou admitir, como cremos, que sofrem um processo de fusão de segmentos sibilantes idênticos.

IV - Contrapõe-se a (III) uma classe relativamente menor de acento na segunda sílaba. Também optam por -zinho. A omissão não rara da consoante final leva à admissão de -inho, incorporando-se então a palavra à classe descrita em (I) tal como abobra e chacra.

$\begin{array}{ll}\text { útil } & \text { utilzinho } \\ \text { revólver } & \text { revolverzinho } \\ \text { revolvinho } & \text { (de revolve, forma popular) } \\ \text { açucar } & \text { açucarzinho } \\ \text { açucrinha } & \text { (de açucra, forma popular) }\end{array}$

V - Um número bastante restrito de palavras acabadas em consoante de acento na terceira sílaba ou de acento na segunda com ditongo na sílaba final optam por -zinho e diferentemente das demais classes em que a marca de plural não provoca alteração acentual, têm o acento avançado uma sílaba para a direita.

$\begin{array}{lll}\begin{array}{ll}\text { a. espécimen, } \\ \text { Lúcifer, }\end{array} & \text { espécime(n)zinho } & \begin{array}{l}\text { especímenes } \\ \text { Júpiter, }\end{array} \\ \text { luciferzinho }{ }^{*} \text { luciferinho } & \begin{array}{l}\text { lucíeres } \\ \text { júpiteres }\end{array} \\ \text { júnior } & \text { Jupiterzinho }{ }^{\star} \text { Jupiterinho } & \\ \text { sênior } & \text { juniorzinho }{ }^{*} \text { juniorinho } & \text { junióres } \\ & \text { seniorzinho }{ }^{*} \text { seniorinho } & \text { seniores }\end{array}$

VI -Palavras acabadas em ditongo oral ligam-se ao paradigma descrito em (III); as que têm ditongo substituível por uma só vogal, empréstimos em geral, levam acento na segunda. Optam por -zinho.
(20) a.troféu trofeuzinho * trofêuinho
b.jérsei jersi, jerse(i)zinho
peráu perauzinho ${ }^{*}$ perauinho
ponei $\sim$ poni, pone $(\mathrm{i})$ zinho

VII- Palavras acabadas em nasal que normalmente são formas de final ditongado recebem acento na sílaba final e optam como todas as palavras de sílaba ramificada pela variante -zinho. A terminação mais geral é -ão e -õe. Algumas têm acento na segunda: bênção, órfão, órgão.

VIII - Palavras terminadas em -EN geralmente, recebem acento na segunda 
sílaba, opondo-se, portanto a (VII). Algumas têm a nasal no radical (a), mas a maioria a recebe por sufixação (b). Somente um pequeno número delas leva acento na sílaba final (c). Todas optam por -zinho, como se o radical contivesse uma nasal final $(\mathrm{N})$.

$$
\begin{aligned}
& \text { a.hómem, homenzinho b.viágem, viagenzinha c. armazém, armazenzinho } \\
& \text { ontem vitágem vintém } \\
& \text { líquen vadiagem alguém }
\end{aligned}
$$

IX- Finalmente depara-se com a classe de palavras terminadas em vogal do radical, que recebem acento na sílaba final. As que admitem marca de gênero ou de número o fazem por aumento de sílabas, preservando o acento original. Tais oxítonas constituem uma classe pequena comparativamente aos termos herdados do latim ou de (outras) línguas romanas mas parece perderem a característica de classe menor pelo acréscimo ao léxico de palavras deste tipo via contato do português com línguas indígenas e africanas. No processo derivacional, a maioria destas palavras revela a presença de uma consoante que está ausente na forma não-derivada. Optam, da mesma forma que as palavras acabadas em consoante, pela variante diminutiva com $/ \mathrm{z} /$.

$$
\begin{aligned}
& \text { café }>\text { cafeteira } \sim \text { cafezinho, } \quad \text { *cafeinho } \\
& \text { chá > chaleira } \sim \text { chazinho, } \quad{ }^{*} \text { chainho } \\
& \text { robô }>\text { robotizar } \sim \text { robozinho, } \quad \text { * roboinho } \\
& \text { siri sirizinho, * } \\
& \text { urubu urubuzinho, *urubuinho }
\end{aligned}
$$

Os seguintes aspectos merecem também ser levados em conta:

$\mathrm{X}$ - A língua possui monossílabos tônicos e átonos como também alguns dissílabos átonos, da mesma forma que possui afixos tônicos e átonos:

$$
\begin{array}{ll}
\text { átonos } & \text { tônicos } \\
\text { a, de, em, para, etc. } & \text { vê, sou, dá, etc. } \\
\text {-eo, des-, in-, etc. } & \text {-eiro, -al, -aço, etc. }
\end{array}
$$

XI - Certos sufixos átonos têm a propriedade de alterar a posição do acento original, entre eles: -dromo -ico, -logo.

$$
\begin{array}{ll}
\text { energia, } & \text { energétíco, enérgico } \\
\text { melancolia, } & \text { melancólico } \\
\text { auto, } & \text { autódromo } \\
\text { geo, } & \text { geólogo } \\
\text { psique, } & \text { psicólogo }
\end{array}
$$


XII - E, finalmente, as poucas palavras herdadas do latim, terminadas em duas consoantes mostram dar preferência ao acento na segunda sílaba. As de entrada mais recente na língua tendem, todavia, a receber acento na sílaba final, como as acabadas em consente em geral o fazem. Algumas apresentam formas alternantes:

$\begin{array}{ll}\text { Palavras tradicionais } & \text { Palavras novas } \\ \text { tórax [tOraks] } & \text { eucatex [ewkatEks] } \\ \text { ônix [óniks] } & \text { durex [durÉks] } \\ \text { látex [1áteks] } & \text { pirex [pirÉks] }\end{array}$

Resumindo o que foi exposto, temos:

I - O acento não ultrapassa o limite da terceira sílaba, ou seja, da antepenúltima.

II - A desinência de número em se tratando de não-verbos, não influi na posição do acento, com exceção de casos em que o limite das três sílabas for ultrapassado.

III - Palavras terminadas em consoante recebem na sua maioria, acento na sílaba final.

IV - Palavras terminadas em vogal do radical recebem acento na sílaba final. Nos processos derivacionais elas exibem, antes do afixo, uma consoante idiossincrática.

V - Palavras com acento na terceira sílaba, que constituem uma classe minoritária, não admitem sílaba intermediária ramificada. Dão preferência, embora acabem em vogal, à variante diminutiva -zinho. Apresentam a variante com -inho desde que ocorra o apagamento de uma sílaba.

VI - As terminações em nasal tendem a puxar o acento para a sílaba final, com a exceção de -eN que dá prioridade ao acento na segunda.

VII - A língua possui sufixos átonos e tônicos. Entre os primeiros existem alguns que, sem acento próprio, causam mudança na posição do acento original. VIII- Palavras terminadas em dupla consoante são tradicionalmente acentuadas na segunda sílaba. Palavras de introdução relativamente recente, o mais das vezes não-dicionarizadas, tendem, todavia, a incorporar-se ao padrão das palavras acabadas em consoante.

Vejam-se os números interessantes que os quadros estatísticos abaixo oferecem como argumento para considerar classe minoritária as palavras acabadas em consoante sem acento final. Foram levantadas, no dicionário de cinco volumes de Caldas Aulete (1958), todas as palavras acabadas em 
consoantes, deixando-se de lado as nasais em virtude de sua complexidade. O resultado está exposto nos quadros 1 e 2.

\begin{tabular}{|c|c|c|c|c|c|c|c|}
\hline & & & \multicolumn{3}{|c|}{ Palavras terminadas em consoantes } & & \\
\hline & oxítonas & & Paroxítonas & & proparoxítonas & & \\
\hline & Ocorr. & Perc. & Ocorr. & Perc. & Ocorr. & Perc. & Total \\
\hline L & 3159 & $65 \%$ & 1665 & $34 \%$ & 2 & $0,09 \%$ & 4858 \\
\hline R & 4081 & $97 \%$ & 105 & $2,5 \%$ & 2 & $0,05 \%$ & 4188 \\
\hline S & 831 & $64 \%$ & 422 & $32 \%$ & 44 & $0,4 \%$ & 1297 \\
\hline Total & 8079 & $78 \%$ & 2208 & $21 \%$ & 57 & $0,55 \%$ & 10344 \\
\hline
\end{tabular}

Quadro 1 - Palavras terminadas em consoante

As três consoantes que aparecem em posição de coda apresentam índices expressivamente mais altos quando o acento incide na posição final, L4, nas oxítonas. Acento na segunda sílaba(paroxítonas) em todas as classes mostram números relativamente baixos. Proparoxítonas acabadas com consoante constituem uma raridade não fora o número, embora pequeno, atribuído à sibilante. Infere-se desses dados que a regra geral para palavras terminadas em consoante é acento na sílaba final.

\begin{tabular}{|c|c|c|c|c|c|c|c|}
\hline & & & \multicolumn{3}{|c|}{ Palavras terminadas em $\underline{\mathrm{ks}}$} & & \\
\hline & $\begin{array}{c}\text { Última } \\
\text { sílaba }\end{array}$ & $\begin{array}{c}\text { Segunda } \\
\text { sílaba }\end{array}$ & $\begin{array}{c}\text { Terceira } \\
\text { sílaba }\end{array}$ & & \\
\hline & Ocorr. & Perc. & Ocorr. & Perc. & Ocorr. & Perc. & Total \\
\hline $\mathrm{KS}(\mathrm{x})$ & 3 & $4 \%$ & 63 & $81 \%$ & 5 & $6 \%$ & 77 \\
\hline
\end{tabular}

Quadro 2 - Palavras terminadas em ks

Embora a ocorrência de palavras dicionarizadas, acabadas em dupla consoante, seja limitadíssima, os índices acima indicam que tais palavras, diferentemente das acabadas em consoante simples, seguem a regra geral: acento na segunda sílaba. Todavia, como foi observado em (24b), palavras não-dicionarizadas, sobretudo rótulos de produtos comercias, mostram acento na sílaba final.

Vamos agora proceder à análise do acento em Português, considerando duas alternativas, ambas fundamentadas no modelo de Halle \& Vergnaud. A primeira, insensível ao peso silábico, estipula a criação de constituintes ilimitados tanto na linha 0 quanto na linha $1 \mathrm{e}$, com certo grau de sofisticação, dá conta dos fatos. A segunda, ao levar em conta a sensibilidade quantitativa da língua, organiza constituintes binários na linha 0 , e apresenta-se formalmente mais simples. 


\section{3-PRMEIRA ALTERNATIVA DE ANÁLISE}

Admitimos desde logo que o algoritmo do acento pode alcançar qualquer palavra independentemente de sua classe. ${ }^{4}$ É que o léxico é pensado à maneira da Fonologia Lexical, o que permite distinguir verbos de não-verbos pelo domínio de aplicação das regras. Em não-verbos, as regras de acento operam no componente lexical, a partir da primeira regra de formação de palavras, a que introduz a vogal temática, e voltam a operar a cada introdução de um novo morfema, durante todo o processo derivativo como regras cíclicas; em verbos, também pertencem ao componente lexical, mas somente operam quando a palavra está pronta, caracterizando-se como não-cíclicas. Na acepção de Booij \& Rubach (1967), são regras lexicais pós-cíclicas.

O domínio do acento lexical, diferenciado, pois, para verbos e nãoverbos é a palavra definida em (27), precisamente, a palavra lexical para não verbos e a palavra morfológica para verbos.

(27) Domínio:

a. Palavra lexical

Radical +VT] [-verbo]

[desinência]

b. Palavra morfológica

Radical +VT+MTA+NP[+verbo]

[desinência]

Comecemos pelas palavras não-verbais (27a.). A exclusão do morfema de número na classe não-verbal é justificada pela Fonologia Lexical. Quando o morfema de plural $\{S\}$ é introduzido na etapa final da formação estrutural da palavra, as regras do stratum cíclico já cessaram de operar. A palavra está pronta. A vogal epentética que aparece em alguns plurais como em pomar > pomares, por exemplo, tem exclusivamente caráter fonético, sendo introduzida tardiamente, depois da aplicação de todas as regras fonológicas (pomar $>$ pomars $>$ pomares)

(28) Procedimentos de atribuição do Acento Primário

a.O domínio do acento é a palavra como definida em (27).

4 Certas preposições e conjunções (palavras formais) que apresentam uma estrutura muito semelhante à da palavra lexical também podem ser caracterizadas quanto à presença ou ausência de uma vogal temática e entrar no mesmo paradigma acentual.

Organon, Porto Alegre, v. 28, n. 54, p. 281-321, jan./jun. 2013. 
b.Os portadores de acento ou elementos acentuáveis são os núcleos silábicos, i.é, as vogais.

c. A extrametricidade incide sobre a última vogal do domínio do acento com status de desinência.

Estrutura métrica:

d.linha 0: constituinte ilimitado, cabeca à direita, com projeção da cabeça na linha 1. Governo: direita/esquerda.

e. linha 1 : constituinte ilimitado, cabeça à. direita com projeção de cabeça na linha 2

f. linha 2: fusão das linhas 1 e 2 com preservação do asterisco mais à direita.

À regra (28) referir-nos-emos como Regra Final (RF). Comecemos pela aplicação do algoritmo em palavras do primeiro ciclo do componente lexical.

\section{1- A palavra em sua forma simples}

Palavras acabadas em VT com acento na segunda sílaba,. que constituem a classe geral, e as que acabam em consoante ou em vogal do radical com acento na sílaba final, são exemplificadas a seguir:

\begin{tabular}{|c|c|c|c|c|}
\hline /kaz+a/ & /pared+e/ & /kafE/ & /koronEl/ & Léxico \\
\hline /kaza/ & & /kafE/ & /koronEl/ & Domínio \\
\hline a a & aee & $\mathrm{AE}$ & $0 \circ \mathrm{E}$ & Portadores \\
\hline$\langle\mathrm{a}>$ & $<\mathrm{e}\rangle$ & $\cdots$ & $\cdots-$ & $\operatorname{Ex}(28 c)$ \\
\hline$\left({ }^{*}\right)$ & $\left({ }^{*}{ }^{*}\right)$ & $\left({ }^{*}{ }^{*}\right)$ & $\left({ }^{*}{ }^{*}\right)$ & Linha 0 (28d) \\
\hline$\left({ }^{*}\right)$ & $\left(.{ }^{*}\right)$ & $\left(.{ }^{*}\right)$ & $\left(.{ }^{*}\right)$ & Linha 1 (28 e) \\
\hline$\left({ }^{*}.\right)$ & $\left(.{ }^{\star}.\right)$ & $\cdots--$ & $\cdots--$ & ASP \\
\hline$\left({ }^{*}\right)$ & $\left({ }^{*}\right)$ & $\left({ }^{*}\right)$ & $\left({ }^{*}\right)$ & Linha 2 (28f) \\
\hline [káza] & [parédzi] & [kafE] & {$\left[\right.$ koronEl] $^{1}$} & \\
\hline
\end{tabular}

Palavras do tipo casa, parede diferem das acabadas em consoante coronel e em vogal de radical café, as duas últimas com comportamentos semelhantes no processo derivativo quanto à aceitação de -zinho, apenas pela extrametricidade, que, como regra geral, alcança somente a vogal de desinência, incluindo a vogal temática, conforme (27a).

Assim café e coronel, sem VT, têm todos os portadores de acento visíveis, enquanto casa e parede trazem invisível a vogal final com status de desinência (VT), frequentemente elidida no paradigma flexional, fato 
já aludido. As vogais invisíveis são incorporadas à palavra pela Regra da Adjunção da Sílaba Perdida (ASP) (Hayes, 1982:235), que faz anexar ao vocábulo uma sílaba leve como membro fraco de um pé adjacente.

Às palavras oxítonas terminadas em consoante que entram no paradigma regular (pomar, funil, amor) contrapõe-se uma classe minoritária com acento na segunda sílaba, (cadáver, lápis, visível) que recebe no léxico o diacrítico extramétrico, em conformidade com (30b):

(30) Palavras marcadas por um diacrítico no léxico possuem:

(a) sílaba extramétrica se acabarem em vogal

(b) rima extramétrica nos demais casos.

$\begin{array}{cccc}{[+ \text { Ex }]} & {[+ \text { Ex }]} & {[+ \text { Ex }]} & \\ \text { /kadaver/ } & \text { llápiS/ } & \text { /vizivel/ } & \text { domínio } \\ \text { A a e } & \text { A i } & \text { I i e } & \text { portadores } \\ <\text { er }> & <\text { is }> & <\text { El }> & \text { Ex }(30 \mathrm{~b}) \\ & & & \text { Linha 0 (28d) } \\ \left({ }^{*} .\right) & \left({ }^{*} .\right) & \left({ }^{*} .\right) & \text { Linha 1 }(28 \text { e }) \\ \left({ }^{*}\right) & \left({ }^{*}\right) & \left({ }^{*}\right) & \text { ASP } \\ {[\text { kadáver }]} & {[\text { lápis }]} & {[\text { vizível }]} & \text { Linha 2 (RF) }\end{array}$

Aqui vale observar que a Regra de Adjunção da Sílaba Perdida só tem o poder de anexar uma vogal ao pé precedente como seu membro fraco. A coda permanece invisível e vem à tona no fim da derivação, como ocorre quando segmentos consonantais são extramétricos.

A Teoria da Extrametricidade de Hayes permite seja ela atribuída, como vimos inicialmente, por meio de regras ou marca lexicais. A primeira tem caráter livre e atinge um grande número de palavras, tal qual o faz (28c), tornando invisível um portador de acento com status de desinência, enquanto a segunda fica restrita a minorias, tal qual o faz (30). Justamente palavras acabadas em consoante que não recebem acento na sílaba final constituem um grupo menor, como tivemos oportunidade de inferir do Quadro 1.

A primeira barreira com que deparamos são as palavras proparoxítonas que, embora em número menor, são relativamente frequentes na linguagem técnica e científica, além de fazerem parte da língua por herança latina. Uma das características deste tipo de palavra diz respeito à vogal da segunda sílaba, que muitas vezes é omitida em dialetos populares - abobra por abóbora, fosfru por fósforo, arvri ou arvi por árvore ou que fica sujeita à, elevação variável, com maior incidência sobre /o/ do que sobre /e fósforo 
$>$ fósfuru, alfândega > alfândigga. Outro aspeto peculiar é que nesta posição a segunda a contar da direita, jamais ocorre sílaba de rima ramificada. Em virtude desta especificidade, ou seja, das três características referentes à vogal da segunda sílaba das proparoxítonas: elevação variável, apagamento variável e restrição da rima que funciona como um filtro, essas palavras, por sua especifidade, recebem o extramétrico no léxico (30a) e ficam sujeitas à regra (32). E como a extrametricidade lexical tem prioridade sobre a extrametricidade do algoritmo acentual (28c), quando essa opera, não as alcança, pois já está oculta a vogal com desinência. O comportamento das palavras de exceção permite declarar que fica proibido incidir acento, ou sela, um asterisco, em sua sílaba final, se for leve. Consequentemente se a aplicação do algoritmo métrico levar um asterisco a locar-se em sílaba que apresenta as três características supramencionadas, a qual no plano do acento corresponde à sílaba leve final, por pressão do sistema, ele é apagado. E segundo predição da Teoria, um novo portador de acento emerge em posição adjacente, oposta à cabeça do constituinte, desde que não haja outros asteriscos no constituinte. Isso é um recurso disponível na teoria de Halle \& Vergnaud. É sobre essas formas que incide a regra (32) incorporada ao algoritmo (28).

(32) Apague *

em sílaba leve, final, se a palavra possuir elemento extramétrico.

Assim a diferença, do ponto de vista prosódico, entre lâmpada e lambada reside em que na última a extrametricidade atribuída por (28c) ou (30a) oculta a vogal da desinência, deixando a vogal da segunda sílaba, agora final, protegida de (32) por uma consoante (lambad $<a>$ ), enquanto a primeira, $($ lâmpa $<d a>)$ deixa visível na posição final uma vogal leve. Sobre essa vogal, o algoritmo (28) coloca o asterisco e (32) dirige a metátese. É dessa forma que parede, cadeira, sargento não são atingidas por (32), assim como repórte $<r>$, revólve $<r>$, com extrametricidade lexical na rima (30b), e tampouco palavras como javali, acarajé, cuja imunidade a (32) se deve a ausência de elemento extramétrico. A derivação que levaria (33) a resultados incorretos, agora é filtrada por

(32), produzindo-se o esperado.

$\begin{array}{llll}{[+\mathrm{Ex}]} & {[+\mathrm{Ex}]} & {[+\mathrm{Ex}]} & \\ / \text { fosfor }+0 / & \text { /lampad }+\mathrm{a} / & \text { /abobor+a/ } & \text { léxico } \\ \text { /fosforo/ } & \text { /lampada/ } & \text { /abobora/ } & \text { domínio }\end{array}$


(30 a)

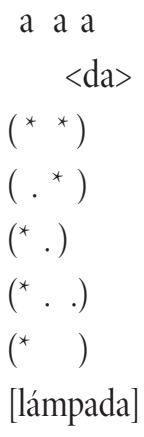

a 0 o a

$<\mathrm{ra}>$

$\left({ }^{*}\right)$

$\left(\ldots{ }^{*}\right)$

$\left(\cdot{ }^{*}.\right)$

$\left({ }^{*} \ldots\right)$

$\left({ }^{\star}\right)$

[abóbora] portadores

$\operatorname{Ex}(30 \mathrm{a})$

Linha 0

Linha 1

Apague *

ASP

RF

saída

Observe-se que (32) somente se aplica na linha 1 . Se operasse na linha 0 , apagaria um elemento acentuável, assim como apagaria o acento principal se operasse na linha 2, aqui representada por RF, pois aí não há elementos permutáveis.

Com respeito às proparoxítonas de consoante final, em número tão restrito que poderiam ser enumeradas, (4\% apenas, cf. Quadro 2), esta análise as coloca no léxico com sílaba extramétrica, razão pela qual ficam sujeitas também à (32).

$\begin{array}{cccc}\text { /iNteriN/ } & \text { /zupiter/ } & \text { /lusifer/ } & \text { Domínio } \\ \text { i e i } & \text { u i e } & \text { u i e } & \text { Portadores } \\ <\text { riN }> & <\text { ter }> & <\text { fer }> & \text { Extramétrico } \\ \left(*^{*}\right) & \left(*^{*}\right) & \left(*^{*}\right) & \text { Linha } 0 \\ \left(.^{*}\right) & \left(.^{*}\right) & \left(.^{*}\right) & \text { Liha } 1 \\ \left(*^{*} .\right) & \left({ }^{*} .\right) & \left(*^{*} .\right) & \text { Apague }{ }^{*}(32) \\ \left(*^{*} .\right) & \left({ }^{*} .\right. & \left(*^{*} .\right) & \text { ASP } \\ \left({ }^{*}\right) & \left({ }^{*}\right) & \left({ }^{*}\right) & \text { RF } \\ {[\text { interin] }} & {[\text { zúpiter] }} & {[\text { lúsifer] }} & \text { saída }\end{array}$

Outro problema que algumas palavras desta classe apresentam são as formas pluralizadas que possuem uma vogal epentética, provocando aumento de sílabas da palavra e conseqüente transgressão do limite máximo em que transita o acento. Proibido o acento na quarta sílaba, a Restrição da Janela, que atua, neste caso, no final da derivação do item lexical, funciona como um filtro, acertando júpiter $>$ júpiteres para júpiteres, por exemplo. No português, como no espanhol e em outras línguas, o acento alcança maximamente a terceira sílaba a contar do fim da palavra. ${ }^{5}$

5 A única aparente exceção que encontramos [ritimiku], com vogal epentética de entrada tardia, alterna com [rítmiku], a forma da subjacência que recebeu acento na terceira sílaba. Isso 
(35) Filtro de saída

Apague * por Restrição da Janela de Três Sílabas (RJT)

$$
\begin{aligned}
& \left({ }^{*} \ldots\right) \quad \text { por RJT }\left(.{ }^{*} . .\right) \quad \text { jupíteres } \\
& \text { jupiter }+\mathrm{s}>\text { júpiters }>\text { júpiteres } \quad---> \\
& \left(.{ }^{*} . .\right) \quad \text { por RJT }\left(.{ }^{*} \ldots\right) \\
& \text { lucifer }+s>\text { lúcifers }>\text { lucíferes } \quad--->\quad \text { lucíferes }
\end{aligned}
$$

É mera coincidência a retomada do acento original (cf. linha 1 em (34)).

Porque inexistem constituintes sem cabeça e porque mudança de acento, assim como movimento de asterisco, está restrita à Condição de Adjacência, abaixo formalizada, a única sílaba disponível no limite da Janela de Três Sílabas é a originariamente acentuada.

(37) Condição de Adjacência (Haraguchi 1991: 140)

O local de aterrissagem para movimento de acento deve ser adjacente à posição da qual o acento foi movimentado.

Com respeito a sénior senióres (e não seníores), um aparente contraexemplo, a ressilabação, precedente à mudança de acento, indica que a vogal alta não ocupou o centro silábico, convertendo-se em glide, uma possibilidade de caráter universal. Então o asterisco, ao deslocar -se, encontra como portador mais próximo a vogal /o/, onde se acomoda. ${ }^{6}$

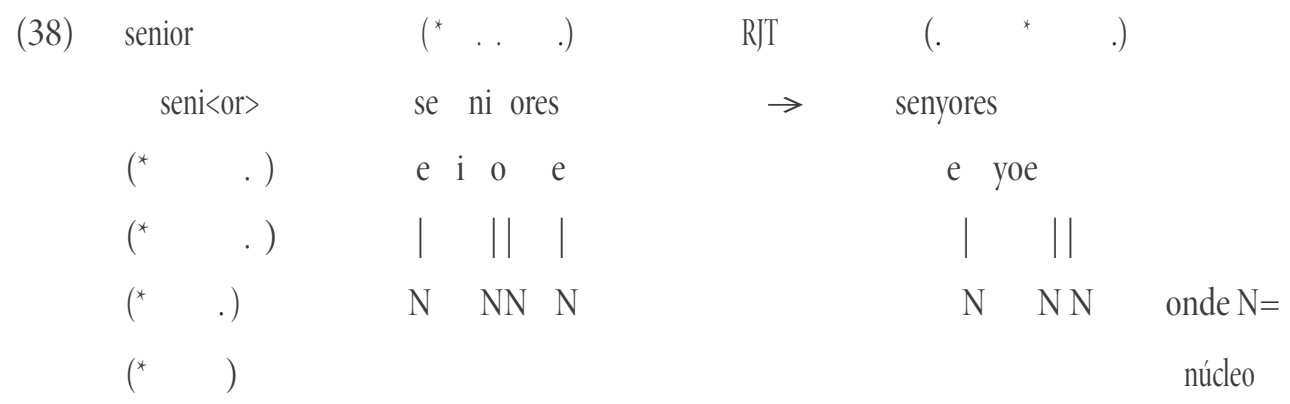

Quanto a caráter caracteres, a restrição das três últimas sílabas não se faz relevante, pois um plural inalterado, carácteres, com epêntese tardia

parece indicar que o filtro das Janelas de três Sílabas somente opera no componente lexical, e que esse caso, assim como os clíticos (diga-se-lhe), em que provavelmente o acento secundário está envolvido, devem pertencer ao nível pós-lexical.

6 Ver Harris (1987:70) para o tratamento da perda de silabicidade em espanhol. 
para formar a sílaba $k i$, não violaria essa restrição, assim como em cadáver, cadáveres. Se a referida epêntese for considerada, [karakitéres], então o avanço de duas sílabas, e não uma, oferece um indício de que essa diferença acentual está fora do controle de RJT.

É com representações subjacentes separadas, ou seja, como se fossem itens lexicais separados, que esse algoritmo acentual considera caráter, caracteres. Não faltam exemplos de plurais lexicalizados: pêsames, núpcias, exéquias. As regras de acentuação operam pois em ambas as palavras, como se o morfema específico de plural fosse parte integrante da estrutura profunda.

$\begin{array}{ccc}{[+\mathrm{Ex}]} & {[+\mathrm{Ex}]} & \\ \text { karater } & \text { karakteres } & \\ <\text { er }> & <\text { es }> & \text { Ex }(30 \mathrm{~b}) \\ \left({ }^{*}\right)<^{*}> & \left({ }^{*}\right)<^{*}> & \text { linha } 0 \\ \left(.^{*}\right) & \left(.{ }^{*}\right) & \text { linha } 1 \\ \left(.^{*}\right) & \left(.{ }^{*} .\right) & \\ \left({ }^{*}\right) & \left({ }^{*}\right) & \text { linha } 2 \\ {[\text { karáter }]} & {[\text { karaktéres }]} & \end{array}$

A presença de uma nova sílaba, produzindo-se a forma mais frequente [karakitéres], deve-se a um /i/ epentético, cuja infixação fica fora do domínio do acento, caracterizando-se como pós-lexical, pois não apresenta condicionamento de estrutura morfêmica.

Finda a análise do acento primário em palavras primeiramente produzidas no componente lexical, passemos a considerá-lo em derivações subsequentes.

\section{2 - Palavras derivadas}

Embora Chomsky and Halle(1968) se tenham valido do acento para exemplificar regras fonológicas cíclicas, algumas propostas relativamente recentes tentaram desvincular o acento desta propriedade. Halle \& Vergnaud (1987), porém, incorporam a ciclicidade a sua proposta, vinculando-a à Teoria da Fonologia Lexical, defendida por Kiparsky (1982, 1985), Mohanan $(1982,1985)$ e muitos outros. Ao invés de falar em stratum lexical e pós-lexical, falam em stratum da palavra interna e stratum da seqüência de palavras e contam com a organização das regras fonológicas em blocos, regras que podem ser atribuídas a mais de um stratum, os quais 
são especificados como cíclicos ou não cíclicos. Ao postularem. de acordo com a Fonologia Métrica, que o plano do acento fica separado do resto da estrutura fonológica, defendem a idéia de que à medida que a palavra vai somando afixos, emergem vários planos, submetendo-se cada um deles ao que denominam Condição de Apagamento do Acento, um processo que apaga toda a informação de acento de ciclos anteriores, desde que o afixo acrescido não seja por si mesmo domínio do acento, por exemplo -eiro, -al. Então as regras operam no novo plano sem marcas prévias . Por outro lado, se os Por outro lado, se os sufixos são por si mesmos domínios de acento, por exemplo, -zinho, -mente, a informação dos passos prévios do ciclo é copiada no novo plano, assim como nos compostos. A Condição de Apagamento do Acento declara:

\section{(40) Condição de Apagamento de Acento ((H \& V, 1987:p.83)}

$\mathrm{Na}$ entrada das regras da strata cíclica, a informação sobre acentos gerados em passos prévios através de regras cíclicas é transferida somente se o constituinte afixado for por si mesmo domínio para regras cíclicas de acento. Se o constituinte afixado não for por si mesmo domínio de acento, a informação sobre acentos atribuídos em passos prévios é apagada.

Por conseguinte no fim da primeira passagem das regras cíclicas de acento, a palavra na sua forma mais simples (casa, café)mostra a sua grade métrica. desenvolvida, a qual será copiada (não porém além da linha 0 ) no novo plano em caso de sufixos especiais ou palavras compostas, como em cafezinho e guarda-roupa, mas será totalmente apagada no caso mais geral de afixação, como em caseiro e cafezal (cf. H\&V,1987:p86).

A Fonologia Lexical nos oferece elementos para uma distinção importante no português, referente aos acentos primário e secundário. O acento primário, que é cíclico, é atribuído no componente lexical, o da formação da palavra; o acento secundário que pode envolver mais de uma palavra é nitidamente pós-lexical. ${ }^{7}$ Outro recurso importante que a Teoria oferece é estabelecer a diferença entre sufixos sensíveis ao acento e sufixos neutros. Neste particular, advogamos com Halle \& Vergnaud que o afixo não-cíclico se diferencia do cíclico por estar representado diretamente no plano da raiz, i.e., a sua introdução no corpo da palavra não passa a formar um novo plano. Então o acento previamente atribuído é preservado.

7 Em Halle \& Vergnaud (1987), encontram-se exemplos de línguas que fazem esta distinção. Roca (1986) defende a ideia de que o acento secundário no espanhol é pós-lexical. Ver também desse autor o artigo de (1990), onde propõe para o espanhol uma estrutura de constituintes de cabeça à direita com o custo de matrizes subespecificadas. 
Levando em conta o exposto, acompanhemos as seguintes derivações: em (41 a,b) o sufixo -oso, sensível ao acento, vai formar um novo plano, em que a informação prévia das regras cíclicas que operaram em amor e número é apagada. Em (4lc), por outra, o acento prévio vem à superfície.

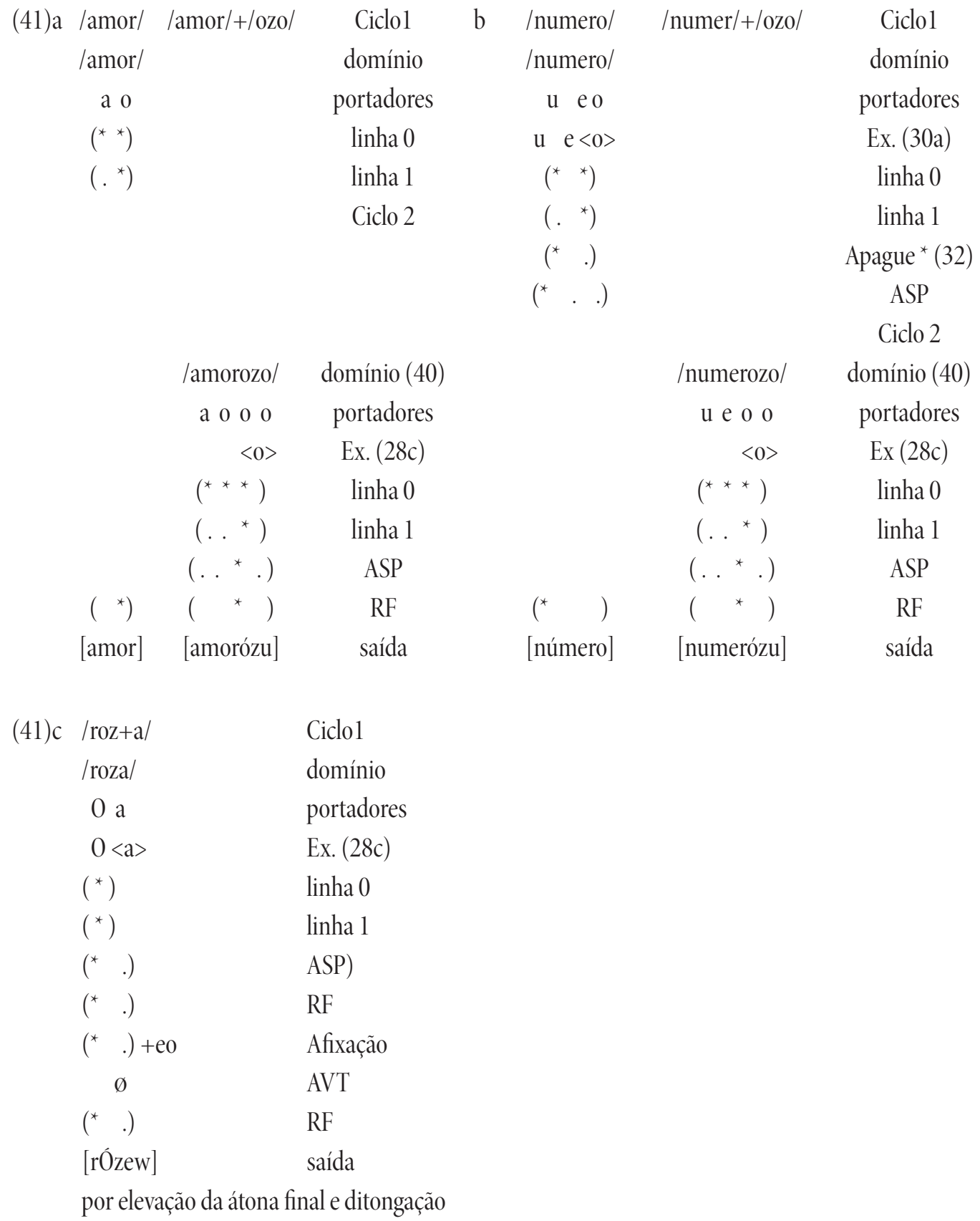

Quando a palavra recebe um sufixo-neutro ou átono, todos os seus constituintes métricos básicos já estão delineados, e nenhuma das regras do algoritmo do acento sobre a nova forma opera. Todavia qualquer 
resultado deste nível pode estar sujeito à Restrição da Janela que como um filtro controla todas as saídas do componente lexical. Assim ao lado de -ico (diminutivo), sensível ao acento, existe -ico (qualidade de), insensível, onde pode intervir a Restrição da Janela de Três Sílabas.

$$
\begin{aligned}
& \text { namóro+ico }{ }^{*} \text { namórico }>\text { namoríco }(\text { por RJT) } \\
& \text { diábo }(\mathrm{l})+\text { ico. }{ }^{*} \text { diábolico }>\text { diabólico }(\text { por R JT) }
\end{aligned}
$$

Não há movimento de acento com sufixos átonos quando o limite não é extrapolado:

$$
\begin{aligned}
& \text { satã } \mathrm{N}+\mathrm{ico}>\text { satánico } \\
& \text { módo + ulo > módulo }
\end{aligned}
$$

Vejamos agora a formação de novos planos com a passagem das regras cíclicas. ${ }^{8}$ Diferentemente de (41), na derivação (44), quando a palavra entra no ciclo 2, traz consigo o constituinte prosódico que formou na linha 0 , no primeiro ciclo. Por conseguinte cafezinho herda uma estrutura métrica.

$$
\begin{gathered}
\text { /kafE/ } \\
\text { /kafE/ } \\
\text { a E } \\
\left({ }^{*}{ }^{\star}\right) \\
\left(.{ }^{*}\right)
\end{gathered}
$$$$
\text { /kafE/+/zino/ }
$$

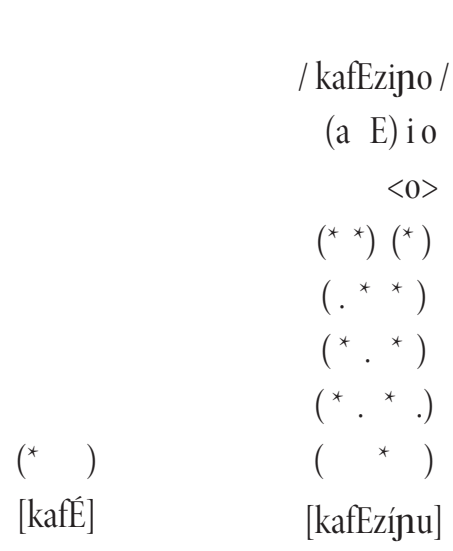

Ciclo1

Domínio (40)

portadores

linha 0

linha 1

Ciclo 2

domínio (40)

portadores

$\operatorname{Ex}(28 c)$

linha 0

linha 1

Evite Choque

ASP

$\mathrm{RF}$

saída

Em (44), ocorre apagamento de asterisco por choque acentual. Trata -se do encontro de dois asteriscos adjacentes, um dos quais é apagado,

8 Em quantos níveis está estratificado o componente lexical do português é uma questão que não será discutida neste artigo, em virtude de envolver complexidades que iriam extrapolar o objetivo deste estudo. 
emergindo um novo asterisco no portador mais próximo em direção oposta à da cabeça do constituinte, que poderá manifestar-se como acento secundário: càfezínho. Não é nosso intento tratar do acento secundário, apenas registramos esse fato como exemplo da tendência do português de rejeitar certo tipo de choque acentual.

Quanto às palavras acabadas em coda de duas consoantes, as que herdam o acento original recebem o diacrítico lexical de extrametricidade por (30b) que torna invisível a rima final(45a); as de entrada mais recente tendem a acomodar-se ao padrão gera $1(45 b)$.

\begin{tabular}{|c|c|c|}
\hline \multirow[t]{2}{*}{ (45)a } & {$[+\mathrm{Ex}]$} & \multirow[b]{2}{*}{ ewkatEks } \\
\hline & tor $<$ aks $>$ & \\
\hline & kod<iks> (códix) & durEks \\
\hline & on<iks> (ônix) & pirEks \\
\hline & lat<eks> (látex) & sedEks \\
\hline & $\left({ }^{*}\right)$ & $\left({ }^{*}{ }^{*}\right)$ \\
\hline
\end{tabular}

Concluído o estudo de palavras não-verbais, passemos agora a examinar os itens das conjugações verbais.

\section{3- Verbos}

De imediato (27) chama a atenção sobre os domínios do paradigma acentual em verbos e não-verbos, fato já aludido. Isso provém de suas diferenças morfológicas (cf.^3), que provoca tratamentos distintos da extrametricidade. Enquanto na classe não-verbal, a extrametricidade recai sempre sobre VT, lâmpada, verde, em verbos. tanto incide em VT, canta, como em MTA, cante. Ambos ficam fora do radical e têm o status de desinência. Além disso, a extrametricidade em verbos também pode incidir no morfema número-pessoa. Esses morfemas são: $\mathrm{o}, \mathrm{i}, \mathrm{u}, \mathrm{S}$, ste, stes $\sim$ des $\sim$ es, moS e $\mathrm{N}$ ( manifestando-se a vogais médias como [i,u]). Excluídos $\{\mathrm{S}, \mathrm{N}\}$, o morfema número-pessoa possui portador de acento. Por conseguinte o domínio da extrametricidade, assim como o do acento, em verbos, é a palavra com todos os seus componentes morfológicos preenchidos, seja MTA, seja NP, como (27b) representa. Em outros termos, enquanto a extrametricidade opera na classe nominal a partir da primeira regra de formação de palavras, ao ser acrescido o primeiro afixo, em verbos, espera que o vocábulo esteja pronto, com todos os seus morfemas, inclusive o de flexão. Todavia, o fato de constantemente as regras de acento 
ignorarem na classe verbal as flexões $\{S, N\}$, presentes em seu domínio, seja ao apresentarem-se isoladamente seja como parte do morfema de númeropessoa, leva à constatação, de que em verbos a extrametricidade atinge a rima toda com a condição de ser a coda representada por uma consoante com status de flexão. Por isso, (28c) é reinterpretado agora por (46), que possui alguma especificidade a mais.

(46) Extrametricidade na classe verbal

a Marque como extramétrica a rima final se essa contiver uma consoante com status de flexão.

b De outra forma, marque a vogal final com status de desinência.

É claro que a condição de periferia tem de ser atendida. Assim, por exemplo, em falas, a última rima é extramétrica por (46a) porque contém uma consoante com status de flexão, da mesma forma o /S/ em cantamos. Também é extramétrico, desta feita por (46b), /e/, morfema modo temporal em cante. Por outro lado, /a/, VT, em cantar (infinitivo), fica isenta de extrametricidade, porque não satisfaz a condição de periferia, e porque a rima final sem flexão não pode ser por ela escondida.

Tomando nomes comparativamente, a última vogal de casa é extramétrica, porque, como vogal temática, pertence à desinência, assim como em menina, morfema de gênero, que ocupa a mesma posição de VT. Não, porém, a última vogal de café, porque pertence ao radical.

$\begin{array}{ccc}\text { /fal }+\mathrm{a}+\mathrm{S} / & / \mathrm{fal}+\mathrm{a}+\mathrm{moS} / & \text { léxico } \\ \text { falaS } & \text { falamoS } & \text { domínio } \\ \text { a a } & \text { a a } 0 & \text { portadores } \\ <\mathrm{aS}> & <0 \mathrm{O}> & \text { Ex }(46 \mathrm{a}) \\ \left(^{*}\right) & \left({ }^{*}\right) & \text { linha } 0 \\ \left(^{*}\right) & \left(.^{*}\right) & \text { linha } 1 \\ \left({ }^{*} .\right) & \left(.^{*} .\right) & \text { ASP } \\ {[\text { fálas] }} & {[\text { falámus] }} & \text { saída }\end{array}$

Passamos a descrever a primeira pessoa do singular do indicativo presente, pressupondo-se que a regra de apagamento da vogal temática(AVT) ocorre antes da aplicação do algoritmo do acento. ${ }^{9}$

9 Harris (1974) e Mira Mateus (1975) postulam que as regras de apagamento da vogal temática e de harmonia verbal são aplicadas antes da regra de atribuição de acento. A relação entre as duas regras e a de abaixamento seria mediada peta regra de acento. Isso é amplamente discutido em Wetzels (1991). 


$\begin{array}{cc}\text { Indicativo pres., } 1^{\text {a }} \text { pess. sing., verbo costurar } \\ \text { Radical VT NP } \\ \text { /kostur }+\mathrm{a}+\mathrm{o} / & \text { léxico } \\ \varnothing & \text { AVT } \\ \text { /kosturo/ } & \text { domínio } \\ 0 \text { u } 0 & \text { portadores } \\ <0> & \text { Ex }(46 b) \\ \left({ }^{*}\right) & \text { linha } 0 \\ \left({ }^{*}\right) & \text { linha } 1 \\ \left({ }^{*} .\right) & \text { ASP } \\ \left({ }^{*}\right) & \text { RF } \\ {[\text { kostúru }]^{2}} & \text { saída }\end{array}$

Quanto aos tempos de futuro, cuja morfologia se presta a diferentes interpretações, este algoritmo pressupõe que sincronicamente não existem diferenças entre eles e os demais tempos verbais. Funciona como MTA -re $\sim$-ra, futuro do presente e -ria futuro do pretérito. $\mathrm{E}\{\mathrm{i}\}$, no futuro do presente, assim como nos tempos de perfeito, é morfema número-pessoa (cf. M. Camara 1975:147).
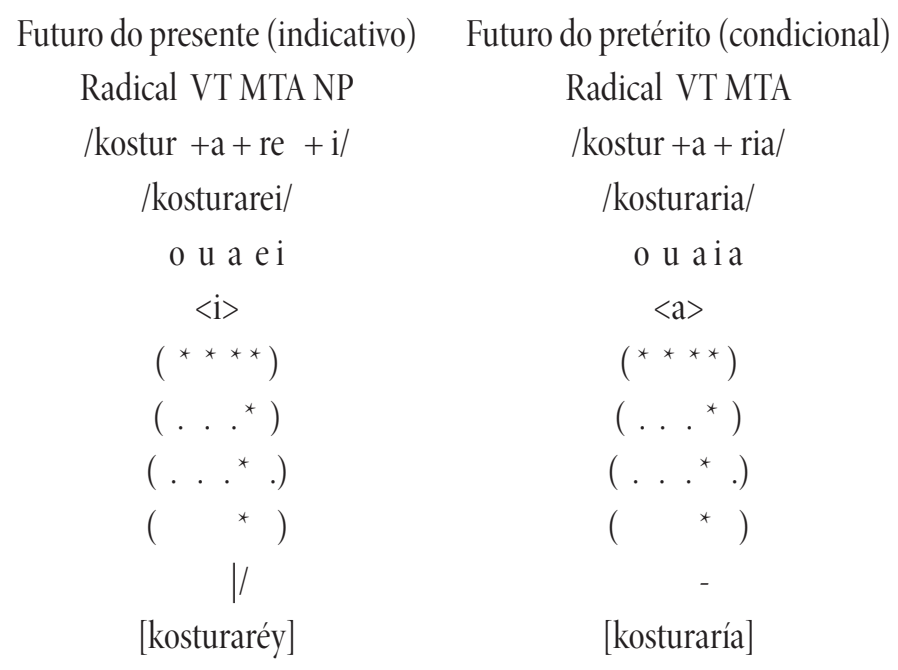

léxico
domínio
portadores
Ex (46b)
linha 0
linha 1
ASP
RF
DI
saída

As formas proparoxítonas da classe verbal estão sujeitas à metátese semelhante à que (32) expressa, mas motivada pelo Filtro do Imperfeito, abaixo formulado, que proíbe acento na vogal do referido monema: -va, -ia, -se, -ria. Neste caso, se o algoritmo acentual vier a colocar um asterisco sobre a vogal desse morfema, ele será apagado por (50) e consequentemente, em conformidade com a teoria, emergirá um novo asterisco em portador 
adjacente à posição precedente, na direção oposta à cabeça de constituinte. Ex: cantávam $<$ os $>$, cantávamos, cantaríam $<0$ os $>$, cantaríamos..

(50) Filtro do Imperfeito (FI)

Apague * em morfemas de imperfeito.

Recapitulemos, por fim, alguns aspectos para ver como os casos básicos do sistema acentual do português são resolvidos.

- da sílaba final pesada puxando o acento café, anzol: o constituinte de cabeça à direita,

- da predominância na língua de palavras paroxítonas, casa, parede: o constituinte de cabeça à direita junto à desinência extramétrica como regra geral.

- de não incidir o acento além da terceira sílaba: o Filtro da Janela de Três Sílabas.

- da diferença entre, por exemplo, útil e sutil: a extrametricidade lexical como marca de minorias.

- das proparoxítonas nominais: o Filtro da Sílaba Leve,

- do acento em proparoxítonas verbais: Filtro do Imperfeito,

- da uniformidade do padrão acentual para verbos e não-verbos: domínios diferentes.

E assim damos por finda a primeira alternativa de análise sobre o acento primário do português, cujo parâmetro fundamental é a estrutura métrica das linhas $\mathrm{O}$ e 1 , que delineiam constituintes ilimitados, de cabeça à direita com governo da direita para a esquerda e três filtros presentes:

Apague *

i) em sílaba leve final;

ii) em morfemas de imperfeito;

iii) por Restrição da Janela de Três Sílabas.

\section{4-SEGUNDA ALTERNATIVA DE ANALISE}

À luz da Fonologia Métrica (Halle \& Vergnaud, 1987), admitindo o parâmetro do peso inerente da rima ramificada (Hayes, 1981), partimos da hipótese de que o acento em português é atribuído pela seguinte regra:

(1) Regra do acento Primário

Domínio: a palavra morfológica

i. Atribua um asterico $\left(^{*}\right)$ à sílaba pesada final, i.é, sílaba de rima ramificada. 
ii. Nos demais casos, forme um constituinte binário (não-iterativamente) com prominência à esquerda, de tipo $\left(^{*}\right.$.) junto à borda direita da palavra.

Com respeito ao domínio, a regra de acento opera na palavra definida em (27) da seção anterior. Recapitulemos: a diferença de estrutura morfológica entre verbos e não-verbos faz com que as regras de acento sejam cíclicas em nomes e adjetivos e não-cíclicas em verbos, significando que nos primeiros pode retornar tantas vezes quantas uma regra morfológica, ou seja, Regra de Formação de Palavras (RFP), venha a ocorrer, até que finde a passagem do ciclo. Como o morfema de plural, $\{S\}$, é introduzido somente quando a palavra está pronta, fica ele fora do domínio acentual. Inversamente, na classe verbal, o algoritmo aguarda que a palavra esteja completamente formada, inclusive com a flexão de número- pessoa inserida.

No que concerne à extrametricidade, em conseqüência do exposto, há um tratamento diversificado para as duas grandes classes. Em não-verbos, incide em exceções, sendo, portanto, uma informação lexical; em verbos, toma a forma de uma regra específica, como veremos oportunamente.

1- Nomes, adjetivos e outros com estrutura lexical similar A extrametricidade é atribuída como um diacrítico lexical a classes minoritárias, que são:

i) palavras com acento na terceira sílaba

ii) palavras terminadas em consoante ou ditongo com acento não-final.

As primeiras recebem extrametricidade na última sílaba e as segundas na consoante final.

O poder da extrametricidade fica, pois, consideravelmente restringido em relação à proposta anterior. Passa a ter somente representação lexical como uma instrução sobre sílabas do tipo: $\operatorname{Ex}\{\}$ ou $\operatorname{Ex}\{c\}$, sílaba ou coda respectivamente, marcando como extramétrica a sílaba ou a consoante final do domínio do acento de itens que pertencem a classes minoritárias.

Observe-se que (1) leva em conta o peso da sílaba. Estamos admitindo que a sílaba tem uma estrutura hierarquizada, cujos constituintes binários se dispõem em ataque-rima com o último dos quais ramificado em núcleo e coda, onde ataque e coda são opcionais. Há rimas leves, í.e, constituídas apenas de um núcleo (V), pato, remo e sílabas pesadas, em que ao núcleo se segue $\mathrm{V}$ ou $\mathrm{C}$ (mau , mar, mel), as quais batizam as sílabas a que pertencem de sílabas leves e sílabas pesadas respectivamente. Por conseguinte sílabas leves são as que possuem rimas simples, não- ramificadas, enquanto sílabas 
pesadas são as que contêm rima complexa, ou seja, ramificada. Há outras maneiras de abordar o assunto diretamente relacionadas à interpretação que se tenha da estrutura silábica. Clements and Keyser (1984: 12), por exemplo, que concebem a sílaba com estrutura plena, apresentam a noção de sílaba leve e pesada em torno da categoria núcleo, como se o núcleo estivesse diretamente ligado ao nó da sílaba. Então sílaba leve é a que possui núcleo não-ramificado, enquanto sílaba pesada é a que contém núcleo complexo. Outra possibilidade seria olhar para a estrutura mórica das palavras, o que segundo Hayes (1989) teria a vantagem de oferecer dupla informação: i) a mora vale como posição fonológica na linha prosódica ou temporal, de modo que um segmento longo será representado apenas por uma unidade melódica ligada a duas moras; ii) a mora estabelece o contraste entre sílaba pesada (duas moras ou mais) e leve (uma só mora). Independentemente da linha seguida, em $(2 \mathrm{a}, \mathrm{b})$ identificam-se sílabas leves e em $(2 c)$ sílabas pesadas. ${ }^{10}$

$\begin{array}{lll}\text { a. } \quad \begin{array}{l}\text { Sílaba leve } \\ \text { casa } \\ \text { sala } \\ \text { verde }\end{array} & \text { b. } & \begin{array}{l}\text { lâmpada } \\ \text { fósforo } \\ \text { hipódromo }\end{array} \\ & & \\ \text { Sílaba pesada } & & \\ \text { troféu } & \\ \text { animal } & \\ \text { pomar } & \end{array}$

Há evidência de que o português é uma língua sensível ao peso da sílaba.

Testemunham em seu favor as sílabas finais de dois segmentos na rima ou de duas moras que na sua maioria atraem o acento (funil, papel), pois $78 \%$ das palavras acabadas em consoantes são oxítonas, como dizem os números estatísticos do Quadro I da primeira seção. Também o fato de proparoxítonas, exemplificadas em (2c), não admitirem rima complexa na penúltima sílaba (cátedra, cadeira, mas não ${ }^{*}$ cádeira) é um indício a mais de que o peso da sílaba é levado em conta pelo sistema acentual.

Voltemos, pois, à regra do acento primário (1), que, na realidade, compreende duas: a regra da Sensibilidade Quantitativa (SQ), (li) atribui um asterisco à sílaba pesada final, ou seja, rima complexa, diagramada como rima ramificada, que porta o acento por inerência. A regra (1iii),

10 Sobre a teoria mórica, ver Hayes, 1989.

Organon, Porto Alegre, v. 28, n. 54, p. 281-321, jan./jun. 2013. 
Formação de Constituintes Prosódicos (FCP), ao estabelecer uma relação de forte/fraco entre duas sílabas, por adjunção de uma sílaba leve à sílaba precedente, cria o constituinte binário mais à direita da palavra. As duas regras são não-iterativas, têm o mesmo governo, i.é, aplicam-se junto à borda direita da palavra, mas não competem pelo mesmo contexto, uma vez que FCP forma um constituinte binário anexando uma sílaba leve à sílaba precedente, e SQ parentetiza a sílaba pesada final. Quando essa encontra contexto adequado, aquela não tem vez. O asterisco criado pelas duas regras é projetado como acento primário da palavra. A essa projeção chamaremos Regra Final (RF). Em suma, a regra da Sensibilidade Quantitativa (1i) reflete o fato de que o português é uma língua sensível à quantidade na atribuição do acento principal da palavra. E a regra de Formação do Constituinte Prosódico mais à Direita (FCP) organiza constituintes de cabeça à esquerda.

O efeito das duas regras é representado em (3), partindo-se do pressuposto de que a atribuição do acento opera quando a palavra tem as suas sílabas estruturadas. Se a primeira silabação é um processo ou faz parte da estrutura subjacente, duas hipóteses em discussão na Teoria, não vem ao caso. Todavia, para melhor entender o mecanismo acentual, que lida com sílabas, seja para combiná-las em pés métricos seja para saber de seu peso, a silabação será sempre indicada nas derivações que seguem. Comecemos por palavras que recebem o acento na segunda sílaba, a partir da borda direita.

Em (3), depois da aplicação da regra morfológica de formação de palavra (RFP), que junta um afixo, no caso a vogal temática, ao radical, têm lugar as regras fonológicas. Assim, identificadas as sílabas, as regras de acento começam a operar.

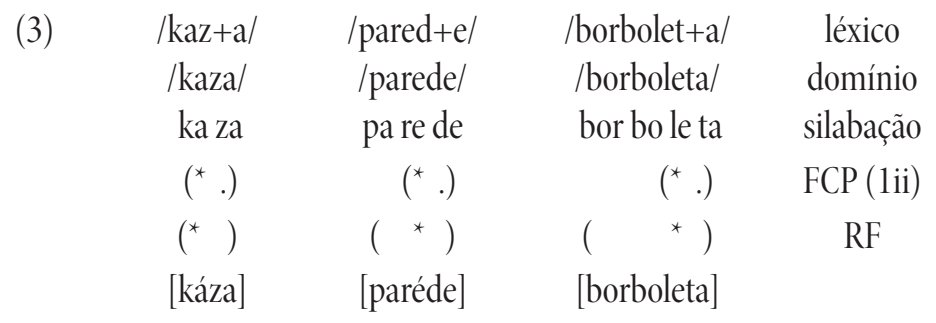

Que no português predominam palavras paroxítonas, acima representadas, é uma informação assaz divulgada. Existe, todavia, um número expressivo de palavras de última rima complexa com acento na silaba final, como resultado de (SQ). Essa classe não possui VT. 


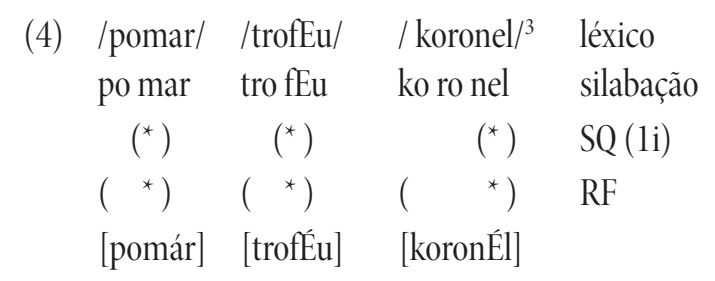

Nas duas classes acima representadas se encaixa a maior parte das palavras do português.

Palavras com acento na terceira sílaba, que constituem uma das classes minoritárias, recebem no léxico a instrução já referida de extrametricidade na sílaba final, tornando-se candidatas a receberem diretamente acento por (FCP). É que com a invisibilidade da sílaba final a segunda sílaba passa a ser a última do domínio do acento, permitindo, por seu caráter de rima leve, que $(\mathrm{FCP})$ a anexe à sílaba precedente para formar um pé binário.

$\begin{array}{cccc}{[+\operatorname{Ex}\{\}]} & {[+\operatorname{Ex}\{\}]} & {[+\operatorname{Ex}\{\}]} & \\ \text { /fOsfor+o/ } & \text { /arvor+e/ } & \text { /numer+o/ } & \text { léxico } \\ \text { fOsforo } & \text { arvore } & \text { numero } & \text { domínio } \\ \text { fOs fo ro } & \text { ar vo re } & \text { nu me ro } & \text { silabação } \\ <\text { ro }> & <\text { re }> & <\text { ro }> & \text { Ex }\{\} \\ \left({ }^{*} .\right) & \left({ }^{*} .\right) & \left({ }^{*} .\right) & \text { FCP } \\ \left(^{*} . .\right) & \left({ }^{*} .\right) & \left({ }^{*} . .\right) & \text { ASP } \\ \left({ }^{*}\right) & \left({ }^{*}\right) & \left({ }^{*}\right) & \text { RF } \\ {[\text { fósforu] }} & {[\text { árvori] }} & {[\text { númeru] }} & \text { saída }\end{array}$

A sílaba invisivel fica, pois, no aguardo da Regra de Adjunção da Sílaba Perdida (ASP), que na formulação de Hayes (1952:235) assim se expressa:

(6) Adjunção da sílaba perdida

Junte a sílaba extraviada ao pé adjacente como membro fraco.

Convenção desta espécie somente se faz necessária após a construção dos pés métricos, se ficarem sílabas avulsas. Se a extrametricidade recair sobre segmentos que incidam em elementos de ceda, a regra (6) não se faz necessária, pois a sílaba já está presente na estrutura subjacente.

Com a mesma sutileza das proparoxítonas, as paroxítonas mencionadas inicialmente que ocultam a consoante final, outra classe menor, deixa à vista também uma janela de duas sílabas, anexando-se ao padrão comum. Em outros termos, a extrametricidade leva as palavras minoritárias, no sistema acentual, a ajustarem-se à FCP, a regra geral. 


\begin{tabular}{|c|c|c|c|}
\hline$[+\operatorname{Ex}\{\}]$ & {$[+\operatorname{Ex}\{\}]$} & {$[+\operatorname{Ex}\{\}]$} & \\
\hline /útil/ & /fasil/ & /vizivel/ & domínio \\
\hline ú til & fa sil & vi zi vel & silabação \\
\hline$\langle\mathrm{l}\rangle$ & $\langle\mathrm{l}\rangle$ & $<\mathrm{l}\rangle$ & Ex \{coda \\
\hline$\left({ }^{*}.\right)$ & $\left({ }^{\star}.\right)$ & $\left({ }^{*}.\right)$ & FCP \\
\hline$\left(\begin{array}{l}* \\
{\left[\text { lútil] }^{\prime}\right.}\end{array}\right.$ & $\left(\begin{array}{ll}* & )\end{array}\right.$ & $\left({ }^{*}\right)$ & $\mathrm{RF}$ \\
\hline
\end{tabular}

Em útil, fácil, visível, tão logo estejam formados os constituintes, manifesta-se a consoante lexicalizada como extramétrica, somente invisível às regras de (1). Por conseguinte a diferença entre útil e sutil, para tomarmos um exemplo, é estabelecida pela marca lexical de extrametricidade sobre a consoante final da primeira palavra. Da mesma forma os pares mínimos do tipo dúvida/duvida, dívida/divida são garantidos pela extrametricidade lexical que recai sobre a última sílaba das proparoxítonas. A extrametricidade, pois, incide em irregularidades idiossincráticas.

A maior barreira que esta proposta encontra são as palavras acabadas em vogal com acento na sílaba final, que, vindas do latim em número relativamente pequeno, ampliaram-se com empréstimos de línguas africanas e indígenas. ${ }^{11}$

Partimos da suposição de que tais palavras recebem acento por SQ em razão de uma consoante abstrata na rima final. Formadas apenas pelo radical, sem a desinência de vogal temática, apresentam-se com uma vogal final de radical plena, jacaré, saci, jacu, diferentemente das que se submetem à regra (1ii), cuja vogal final é reduzida. A proposta é que recebem acento pela mesma regra que atua em pastel, pomar funil, em virtude de a regra (1) visualizar a consoante idiossincrática registrada em seu item lexical, que somente vem à superfície em palavras derivadas. Desta forma as palavras sem VT, cujo elemento terminal pode ser:

(i) uma consoante: pomar, funil

(ii) uma vogal plena: saci, jacaré.

constituem uma categoria só, em virtude de um artifício morfológico cujo mecanismo interno consistente é levado em conta pela Regra do Acento Primário. O caráter idiossincrático da referida consoante, que nas

11 Com referência às oxítonas terminadas em vogal, Pardal (1985), que fez um estudo do acento do Português, à luz da Fonologia Métrica, valendo-se do diagrama-árvore, condiciona o pé forte da sílaba final à não-existência de uma vogal no radical. 
línguas romanas é diacronicamente documentada, pode ser apreciado nos exemplos que seguem: ${ }^{12} 15$

(8)

abecê- abecedário

abricó- abricote, abricoteiro

café- cafeteira, cafezal

Maomé- maometano

rooô-robotizar, robótico

tingui (planta da família das teguminosas) tinguijar,tinguijada

tricô - tricotar.

Exemplos como os que seguem que em virtude da raiz monossilábica são acentuados por si mesmos, em conformidade com a teoria de Halle \& Vergnaud, também são lembrados apenas para mostrar que a presença da consoante no paradigma derivacional de oxítonas acabadas em vogal é uma característica da classe.

(9)

chá - chaleira

nu- nudez, nudação, nudismo, desnudar

nó- nódulo, nódoa

pé- pedal, pedágio, pedestre

pá- pazada

só- solidão, solitário.

$12 \mathrm{O}$ aparecimento de uma consoante imprevisível nas demais classes ocorre por vezes sem a consistência das oxítonas: mato, matagal, cauda, caudatário, erva, ervatário, lama, lamaçal, diabo diabólico. Fazemos a seguinte distinção: Na derivação de café > cafeeiro, por exemplo, em que a consoante não se manifesta, temos o seguinte padrão silábico:

CVCVC

I I I I I

$\mathrm{k}$ a f E -eiro, onde não se faz a ligação com a consoante final do padrão, que, por convenção, desaparece. Na derivação de clusters, sim, temos todas as linhas de associação ligadas:

CVCVC

I I I 1

$\mathrm{k}$ a f et + eira.

Por outro lado, em casos como lamaçal, o padrão silábico assim se apresenta:

, $\mathrm{crcv}$

$\begin{array}{lll}1 & 1 & 1\end{array}$

la ma + al, com uma regra que introduz C (s) antes de um sufixo com vogal inicial $\{$-al $\}$.

Organon, Porto Alegre, v. 28, n. 54, p. 281-321, jan./jun. 2013. 
Por outro lado, com respeito ao diminutivo, optam pelo sufixo -inho, tal como as palavras acabadas em rima ramificada (cf. seção 2):

chalé> chalezinho, ${ }^{*}$ chaleinho;

sofá > sofazinho, ${ }^{*}$ sofainho;

tabu> tabuzinho, ${ }^{*}$ tabuinho;

chaminé> chaminezinho, ${ }^{*}$ chamineinha

A mesma opção fazem com outros sutixos que apresentam a variante com

$$
\begin{aligned}
& \text { aracá }>\text { araçazeiro } \\
& \text { araçaC }>\text { araçaz-eiro } \\
& \text { abacaxi }>\text { abacaxizeiro } \\
& \text { abacaxi }>\text { abacaxiz-eiro } \\
& \text { dendê (planta) }>\text { dendezeiro } \\
& \text { dendêC }>\text { dendez-eiro } \\
& \text { imbu }>\text { imbuzeiro } \\
& \text { imbuC }>\text { imbuz-eiro } \\
& \text { jatai }>\text { jataizeiro } \\
& \text { jataiC }>\text { jataiz-eiro } \\
& \text { picolé }>\text { picoiezeiro } \\
& \text { picoleC }>\text { picolez-eiro } \\
& \text { sofá }>\text { sofazão } \\
& \text { sofaC }>\text { sofaz-ão. }
\end{aligned}
$$

Por vezes, a consoante abstrata se manifesta no paradigma flexional:

$$
\begin{array}{ll}
\text { jacá }(\mathrm{sg}), & \text { jacazes }(\mathrm{pl}) \\
\text { biribá }(\mathrm{sg}), & \text { biribases }(\mathrm{pl})
\end{array}
$$

Não faltam exemplos de hiatos, o que também oferece argumentos: café>cafeeira, cipó > cipoal, cipoada.

Esses fatos testemunham em favor da idéia de que esta classe de palavras, de radical acabado em vogal, sem vogal temática, possui na subjacência uma sílaba final bimórica, ou seja, uma rima pesada, cujo elemento terminal interpretamos como uma consoante abstrata. No nível da palavra nãoderivada, a consoante abstrata, que ainda se encontra na posição de rima, 
nuC; caféC, apaga-se por convenção. No nível da derivação, por ressilabação, passa para a posição de ataque ('onset') e vem à superfície: nudez, cafeteira.

\begin{tabular}{|c|c|c|c|}
\hline $\begin{array}{l}\text { /pomar/ } \\
\text { po mar }\end{array}$ & $\begin{array}{c}\text { /kafEC/ } \\
\text { ka fE }\end{array}$ & / kafeC/+/eira / & $\begin{array}{c}\text { Ciclo } 1 \\
\text { domínio } \\
\text { silabação }\end{array}$ \\
\hline \multirow[t]{4}{*}{$\left({ }^{*}\right)$} & $\left({ }^{*}\right)$ & & SQ (1i) \\
\hline & & / kafeteira / & Ciclo 2 \\
\hline & & ka fe tei ra & silabação \\
\hline & & $\left({ }^{*}.\right)$ & FCP \\
\hline$\left({ }^{*}\right)$ & $\left({ }^{*}\right)$ & $(\quad *)$ & RF \\
\hline--- & $\emptyset$ & --- & Por convençã \\
\hline
\end{tabular}

As regras de acento começam no nível 1, onde se faz contexto para a aplicação de SQ, obtendo-se os resultados corretos de pomar e café. No nível 2, os afixos cíclicos são introduzidos e, de acordo com a teoria de $\mathrm{H} \& \mathrm{~V}$, a informação do plano prévio do acento é obliterada. Então (FCP) produz corretamente cafetéira.

A estrutura subjacente defendida para as palavras terminadas em vogal do radical e representada em (13) diminui o número de pés defectivos que recebem, de acordo com a Teoria, acento por si mesmos. Palavras deste padrão silábico, se nomes e adjetivos, são lexicalizadas com uma consoante abstrata, até mesmo quando monossilábicas, como chá chaleira, pé pedal, possuindo, pois, acento inerente, o que (li), ao lhes atribuir asterisco, indica.

Retomando a extrametricidade, apreciemos em (14), comparativamente, casos de invisibilidade de coda e de invisibilidade de sílaba, e em (15) como as categorias obedecem à Restrição da Janela de Três Sílabas, segundo a qual o acento alcança maximamente a terceira sílaba a contar da borda direita.

$\begin{array}{cccc}{[+\operatorname{Ex}\{c\}]} & {[+\operatorname{Ex}\{c\}]} & {[+\operatorname{Ex}\{\}]} & \\ \text { karater } & \text { lápis } & \text { lusifer } & \text { domínio } \\ \text { ka ra ter } & \text { la piS } & \text { lu si fer } & \text { silabação } \\ <<> & <\text { S }> & <\text { fer }> & \text { extramétrico } \\ \left({ }^{*} .\right) & \left({ }^{*} .\right) & \left({ }^{*} .\right) & \text { FCP } \\ --- & --- & \left({ }^{*} .\right) & \text { ASP } \\ \left({ }^{*}\right) & \left({ }^{*}\right) & \left({ }^{*}\right) & \text { RF } \\ {[\text { karáter }]} & {[\text { lápis }]} & {[\text { lúsifer }]} & \text { saída }\end{array}$

São poucas as palavras que recebem a marca de extrametricidade em sílabas de rima pesada como em Lúcifer. Observe-se que no caso de Organon, Porto Alegre, v. 28, n. 54, p. 281-321, jan./jun. 2013. 
invisibilidade de sílaba com rima complexa (lúcifer, por exemplo), a Regra de Adjunção de Sílaba Perdida tem somente a propriedade de ligar sílabas leves. Ela esquece a consoante final, que segue o padrão, reaparecendo assim que o mecanismo de atribuição de acento chegue a seu término, como em todos os casos de consoante extramétrica.

Deixando de lado lápis, invariável no plural, observemos que o contorno de paroxítona obtido em caráter e de proparoxítona em Lúcifer não é preservado no plural, contrariando a regra geral. Seguimos aqui as considerações feitas na abordagem anterior. Com respeito a [karakitéres], consideramo-lo plural lexicalizado, recebendo acento, independentemente da forma de singular. As demais, ao criarem nova sílaba via vogal epentética, levam o acento a ajustar-se automaticamente ao limite das três sílabas. Os parâmetros que a Teoria oferece para descrever apagamento ou movimento de asteriscos foram formulados como princípio universal por Haraguchi (1991), já referido. É Apague *, que leva o asterisco para a silaba seguinte, sob pressão da Restrição da Janela (RJT).

$\begin{array}{cccc}\text { Sg } & & \text { Pl } & \\ \text { lúci<fer> } & \rightarrow & \text { lucíferes } & \text { Apague }^{*} \\ \left({ }^{*} .\right) & (\mathrm{RTJ}) & \left(.{ }^{*}\right) & \\ \text { júpi<ter> } & \rightarrow & \text { jupíteres } & \text { Apague }^{*} \\ \left({ }^{*} .\right) & (\mathrm{RTJ}) & \left(.{ }^{*}\right) & \end{array}$

Por último, vale notar que as poucas palavras do português de sílaba superpesada (códix, tórax), dicionarizadas, têm acento primário não-final (ver Quadro 2), o que permite afirmar que a sílaba de dupla consoante na coda está envolvida com a extrametricidade, permitindo uma afirmação de caráter geral:

(16) Condição de sílaba superpesada

A sílaba superpesada possui coda extramétrica

\begin{tabular}{|c|c|c|c|}
\hline onikS & tOrakS & latekS & domínio \\
\hline o niks & to raks & la teks & \\
\hline$\langle\mathrm{kS}\rangle$ & $\langle\mathrm{kS}\rangle$ & $<\mathrm{kS}>$ & Ex (16) \\
\hline$\left({ }^{*}.\right)$ & $\left({ }^{\star}.\right)$ & $\left({ }^{*}.\right)$ & FCP \\
\hline$\left(\begin{array}{ll}* & )\end{array}\right.$ & $\left(\begin{array}{ll}* & )\end{array}\right.$ & $\left(\begin{array}{ll}* & )\end{array}\right.$ & $\mathrm{RF}$ \\
\hline [ónikS] & [tÓrakS] & [látekS] & saída \\
\hline
\end{tabular}


Lembremos, todavia, que palavras novas, não-dicionarizadas na sua maioria, com essa terminação, tendem a receber acento por SQ: eucatex, duréx, piréx, o que mostra uma mudança em direção à sensibilidade quantitativa, o padrão geral.

\section{2- Verbos}

Com respeito ao verbo, sujeito às mesmas regras expressas em (1), esse algoritmo, sensível ao peso silábico, interpreta como sílaba leve toda sílaba final acabada em $\mathrm{S}$ ou $\mathrm{N}$ com status de desinência: faleN, falaS. No caso de palavras proparoxítonas, a extrametricidade envolve a sílaba toda. Por conseguinte, a extrametricidade, que neste modelo é atribuída a alguns itens, em verbos toma a forma de uma regra específica:

(18) A extrametricidade em verbos Marque como extramétrico:

i. A sílaba final da primeira e da segunda pessoa do plural das formas de imperfeito.

ii. Nos demais casos, marque a coda que porte elementos com status de flexão, ou seja, $\{\mathrm{N}, \mathrm{S}\}$.

Exemplifiquemos:

\begin{tabular}{|c|c|c|c|}
\hline (Pres., $2^{\text {a }}$ p. sg) & (Imper., $2^{\mathrm{a}}$ p.sg) & (Imper., $1^{\text {a }}$ p. pl.) & \\
\hline /kaNtaS/ & /kaNtavaS/ & /kaNtavamoS/ & domínio \\
\hline $\mathrm{kaN}$ taS & $\mathrm{kaN}$ ta vaS & kaN ta va moS & silabação \\
\hline$<\mathrm{S}>$ & $\langle\mathrm{S}\rangle$ & $<\mathrm{moS}>$ & $\operatorname{Ex}(18)$ \\
\hline$\left({ }^{*}.\right)$ & $\left({ }^{\star}.\right)$ & $\left({ }^{*}.\right)$ & FCP \\
\hline--- & --- & $(*$ & ASP \\
\hline$\left(\begin{array}{ll}* & )\end{array}\right.$ & $(*)$ & * & RF \\
\hline [kántas] & [kantávas] & [kantávamus] & \\
\hline
\end{tabular}

Um caso de pé defectivo, nesta abordagem, são as formas verbais de futuro, admitindo-se que sua origem locucional, atribuída à combinação do infinitivo do verbo que se quer conjugar com formas do presente ou do pretérito imperfeito do verbo haver, futuro e condicional respectivamente, tem ainda reflexos na sincronia. Os que defendem esta hipótese, entre eles Mattoso Câmara (1975: 132) e Luft (1976:27-29), trazem como evidência o uso do pronome clítico em mesóclise: cantar-te-ei, falar-lhe-ia. $\mathrm{O}$ acento primário, segundo a proposta aqui defendida, oferece mais um argumento 
em favor desta colocação. Cada uma das duas partes que compõem o futuro mantém a sua autonomia, tal qual o fazem as palavras compostas, recebendo acentos primários individuais, dos quais somente o último permanece por efeito de Apague *, sob a condição de choque acentual de grau 1 que o português tende a rejeitar. ${ }^{13}$

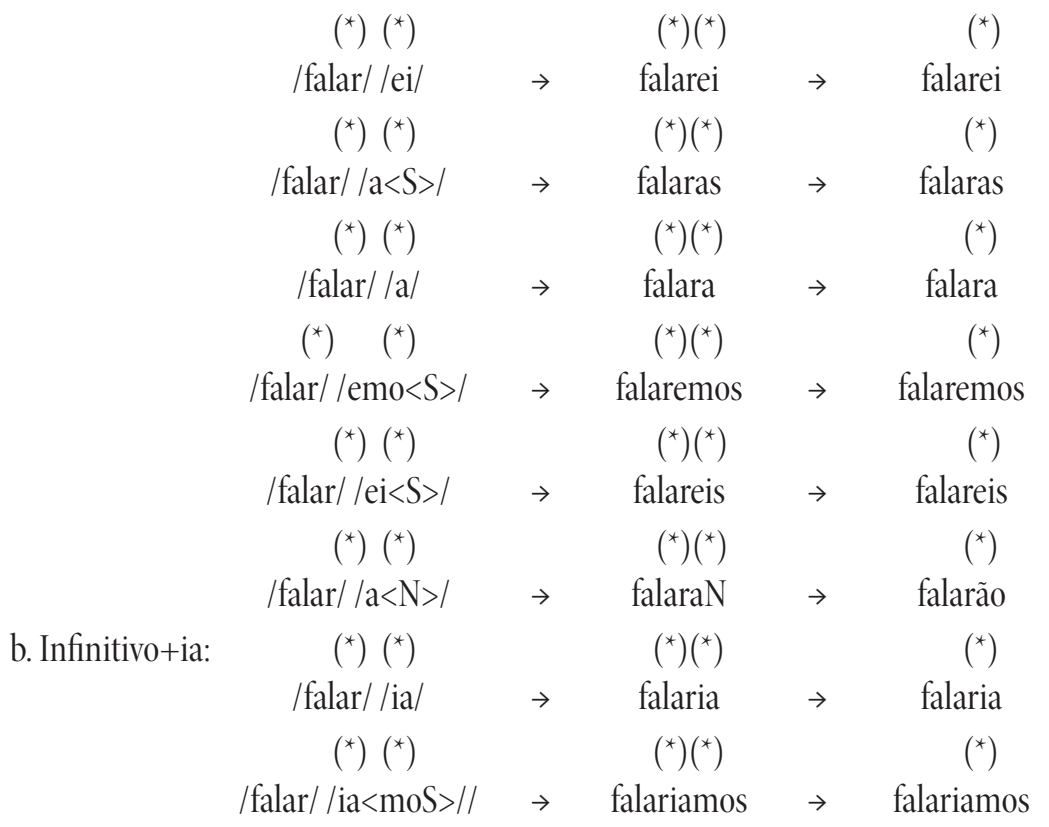

E assim chegamos ao fim desta análise.

\section{CONCLUSÃO}

A abordagem que considera a sensibilidade da língua para o peso da sílaba final, estrutura constituintes binários com cabeça à esquerda e destina a extrametricidade às classes menores, ou seja, às proparoxítonas e às palavras acabadas em sílaba ramificada sem acento final. Em verbos atinge somente itens com flexão. Essa análise tem sobre a primeira alternativa algumas vantagens: faz uso restrito da extrametricidade, não precisa recorrer à regra de apagamento de asterisco, que tem o efeito de uma metátese, nem ao filtro do imperfeito para dar conta das proparoxítonas. Para resolver a única barreira encontrada, o das oxítonas acabadas em vogal, vale-se do recurso morfológico de trazer para o domínio do acento

13 Quanto à hierarquia de choques acentuais, ver Haraguchi, 1991, p. 140.

Organon, Porto Alegre, v. 28, n. 54, p. 281-321, jan./jun. 2013. 
a consoante idiossincrática que tais itens registram lexicalmente e que manifestam em processos derivacionais.

A primeira alternativa, a que não leva em conta o peso silábico, estrutura constituintes não-limitados de cabeça à direita e faz uso mais generalizado da extrametricidade, que incide sobre toda vogal final com status de desinência, mas também se vale, em casos de exceção, da extrametricidade lexical e mais filtros do que a precedente. Comparativamente, podese afirmar que a concepção do acento como se fosse insensível ao peso complica desnecessariamente a análise.

\section{REFERÊNCIAS BIBLIOGRÁFICAS}

Booij, G. and J. Rubach. Postcyclic versus Postlexical Rules in Lexical Phonology. Linguistic Inquiry, V.18, n.1, 1987.

Câmara Jr., J. M. Estrutura da língua portuguesa. Petrópolis: Vozes, 1970.

Câmara Jr., J. M. História e Estrutura da Língua Portuguesa. PadrãoLivraria Editorial Ltda., 1975.

Chomsky, N. and M. Halle. The sound pattern of English. New York: Harper \& Row, 1968.

Halle, M. and J. R. Vergnaud. An essay on stress. Cambridge, MIT Press, 1987. Hammond, M. Constraining Metrical Theory. A modular theory or rhythm and destressing. Doctoral dissertation. UCLA, Los Angeles. Distributed by Indiana University Linguistics C1ub, 1984.

Haraguchi, S. A theory of stress and accent. Holland, Foris, 1991.

Harris, J. H. Syllable Structure and Stress in Spanish. Cambridge. MIT Press, 1983.

Harris, J. H. The accentual patterns of verb paradigms in Spanish. Natural Language and Linguistic Theory. V.5, p. 61-90, 1987. Harris, J. H. How different is verb stress in Spanish. Probus, 1.3, 241-58, 1989. Harris, J. H. Evidence from Portuguese for the "Elsewhere Condition" in Phonology. Linguistic lnquiry 5, 61-8O, 1974.

Hayes, B. A Metrical Theory of Stress Rules. Doctoral dissertation.

Distributed by Indiana University Linguistics. Club, Bloomington, Indiana, 1981.

Hayes, B. Extrametricality and English stress, Linguistic Inquiry, 13, 227

- 76, 1982.

Hayes, B. Compensatory lenghthening in moraic phonology. Linguistic Inquiry, 2O: 253- 306, 1989. 
Kiparsky, Paul. Lexical morphology and phonology. In I.-S. Yang (ed.) Linguistics in the morning calm. Seoul: Hanshin, 1982. p.:3-91. Hayes, B. Some consequences of lexical phonology. Phonology Yearbook, v.2, p85-138,1985.

Liberman, M. 1975. The intonational system of English. Unpublished doctoral dissertation. Cambridge, Mass. M I T. Distributed by the Indiana University Linguistic Club, 1973.

Liberman, Mark \& Alan Prince. On stress and linguistic rhythm. V. 8, 1977. p. 249-325.

Luft, C. Para uma análise morfológica do verbo em português. Dissertação de Livre Docência. Porto Alegre, Editora Emma, 1976.

Mateus.M H. M. Aspectos da Fonologia Portuguesa. Lisboa, Publicações do Centro de Estudos Filológicos, 19, 1975.

Mohanan, K. P. Lexical Phonology. PhD dissertation, MIT. Distributed by Indiana University Linguistics Club, 1982.

Mohanan, K. P. Syllable structure and lexical strata in English. Phonology Yearbook 2 (1985). p 139-155.

Pardal, E D’A. O acento de palavra em português. Comunicação apresentada no Colloquium on Spanish, Portuguese and Catalan Linguistics, Universidade de Georgetown, 1985. Prince, A. Applying Stress. Unpublished ms. Amherst, University of Massachusetts, 1976.

Prince. A. Relating to the grid. Linguistic Inquiry, v. 14:, n 1, p. 19100,1983.

Roca, I. Theoretical implications of Spanish word stress. Linguistic Inquiry, 18, 393-423, 1988 .

Roca, I. Secondary stress and metrical rhythm. Phonology, v.3, May 1986, p 341-370

Roca, I. Diachrony and synchrony in Spanish stress. Journal of Linguistics, v26, no.n1, 1990 March, p133-164.

Roca, I. Morphology and verbal stress in Spanish. Probus, v. 2, n 3, 1990, p.321-350.

Selkirk, E. The role of prosodic categories in English word stress.

Linguistic Inquiry, 11, 563-605, 1980.

Sluyters W. Length and stress revisited: a metrical account of diphthongization, vowel lengthening : consonant gemination and wordfinal epenthesis in modern Italian. Probus, p. 65-102,1990.

Wetzels, W.L. Harmonizacão Vocálica, truncamento, abaixamento e neutralização no sistema verbal do Português: uma análise autosegmental. Cadernos de Estudos Linguísticos, 21, Campinas, 25-58, 1991. 


\section{Notas:}

1 [koronEl koronEw] são variantes presentes no dialeto gaúcho, de onde provêm nossos dados.

2 O levantamento da média final é uma regra geral da língua, que não está sendo referida nas derivações, mas subentendida.

3 A suposição de que tais palavras terminem em vogal na forma subjascente, recebendo acento pela regra que cria constituintes prosódicos, alcançaria o resultado correto, mas teria de contar com uma regra de apagamento de vogal que apagaria também vogais que uso podem desaparecer. 